Published in final edited form as:

Апnи Rev Genet. 2009 ; 43: 95-118. doi:10.1146/annurev-genet-102108-134850.

\title{
The Role of Mitochondria in Apoptosis ${ }^{*}$
}

\author{
Chunxin Wang and Richard J. Youle \\ Biochemistry Section, Surgical Neurology Branch, NINDS, National Institutes of Health, \\ Bethesda, Maryland 20892 \\ Richard J. Youle: youler@ninds.nih.gov
}

\begin{abstract}
Mitochondria play key roles in activating apoptosis in mammalian cells. Bcl-2 family members regulate the release of proteins from the space between the mitochondrial inner and outer membrane that, once in the cytosol, activate caspase proteases that dismantle cells and signal efficient phagocytosis of cell corpses. Here we review the extensive literature on proteins released from the intermembrane space and consider genetic evidence for and against their roles in apoptosis activation. We also compare and contrast apoptosis pathways in Caenorhabditis elegans, Drosophila melanogaster, and mammals that indicate major mysteries remaining to be solved.
\end{abstract}

\section{Keywords}

Bcl-2; bax; cytochrome c; apoptosome; Drosophila; Caenorhabditis elegans

\section{INTRODUCTION}

It is normal to give away a little of one's life in order not to lose it all.

-Albert Camus

Life and death is not just a continuous subject of philosophy but also a tough decision our built-in cellular machinery has to make every moment. Whereas single-cell organisms try to survive by rapid propagation, multicellular organisms have evolved a self-demise mechanism to remove infected, damaged, and unwanted cells so that the whole can better survive. This programmed cell death follows specific patterns such as shrinkage of the cell, margination of chromatin, and nuclear fragmentation and was dubbed apoptosis (64). We have witnessed explosive progress over the past two decades in the field, not only because apoptosis is an evolutionarily conserved mechanism that governs normal body sculpture, homeostasis, defense against pathogen invasion, and genotoxic stress but also because deregulation of apoptosis leads to cancer and immune diseases.

\footnotetext{
*The U.S. Government has the right to retain a nonexclusive royalty-free license in and to any copyright covering this paper. DISCLOSURE STATEMENT

The authors are not aware of any affiliations, memberships, funding, or financial holdings that might be perceived as affecting the objectivity of this review.
} 
At the heart of apoptosis regulation is the activation of caspases, a group of cysteine proteases that can cleave many cellular substrates to dismantle cell contents (112). Caspases exist as inactive zymogens or proenzymes. During apoptosis, the procaspase is proteolytically cleaved to generate a small subunit and a large subunit. The two cleaved fragments form a heterotetramer, which is the active form of the enzyme. Activation of caspases is a downstream event in apoptosis pathways and blocking caspase activity has been shown to eliminate almost all programmed developmental cell death in Caenorhabditis elegans (154). Hence, activation of caspases must be and is indeed under tight control. There are two major apoptotic pathways: extrinsic and intrinsic pathways responding to different signals in vertebrates (see sidebar, Extrinsic apoptosis pathway). The intrinsic pathway is also called the mitochondrial pathway owing to the essential involvement of mitochondria (Figure 1), which is not only the site where antiapoptotic and proapoptotic proteins interact and determine cell fates, but also the origin of signals that initiate the activation of caspases through various mechanisms. For example, cytochrome c (Cyt c) is a key component of the apoptosome complex for activation of the initiator caspase-9. After release from mitochondria, Smac (second mitochondria-derived activator of caspase) and Omi can both bind to inhibitors of apoptosis (IAPs) and relieve their inhibitory effects on caspase activity. These mitochondrial proteins are not dedicated killers, and they perform various essential mitochondrial functions for normal cell growth. The spatial separation of mitochondrial proteins from their interacting partners or targets is a safeguard mechanism to prevent unwanted activation of apoptosis in healthy cells. Only after appropriate release can they switch to become lethal.

Many topics regarding the regulation of mitochondrial function by the B cell lymphoma-2 (Bcl-2) family proteins, the role of mitochondrial morphology in apoptosis, the mitochondrial outer membrane permeability (MOMP), and permeability transition pore complex (PTPC) have been recently reviewed $(19,73,121,152)$. Therefore, here we mainly focus on the mitochondrial proteins that are released during apoptosis and whether or not mitochondria play similar essential roles in invertebrate cell death. Emphasis is made on genetic data so that genes' physiological roles can be fairly dissected. We also discuss challenges that are required to solve some remaining mysteries.

\section{A BRIEF HISTORY}

In their seminal paper, Kerr et al. stated that mitochondria appear to be normal during apoptosis (64). Hence, it was originally assumed that cellular suicide was controlled at the nuclear level. However, it was soon found that de novo translation and transcription are dispensable in most models of apoptosis. In addition, apoptosis occurs normally in enucleated cells (59), implying that apoptosis must be regulated at the cytoplasmic level. The first hint that apoptosis might be regulated at the mitochondrial level came when Bcl-2 was reported to be localized in the mitochondrial inner membrane (actually it is on the outer membrane) (52), and the lack of the C-terminal transmembrane domain reduced the ability of Bcl-2 to inhibit apoptosis (53). Cell-free apoptosis in Xenopus egg extracts was later shown to require an organelle fraction enriched in mitochondria (99). Soon, mitochondrial permeability transition (PT) was reported to be a critical event of apoptosis as the point-ofno-return (74), and mitochondrial control of apoptosis was proposed (156). In the same year, 
Cyt $\mathrm{c}$ was found to be essential for caspase activation by Xiaodong Wang's group (86). Only one year later, back-to-back papers demonstrated that the release of Cyt $\mathrm{c}$ from mitochondria is a primary site for Bcl-2 regulation of apoptosis $(69,146)$, firmly establishing an active role of mitochondria in apoptosis.

However, despite a wealth of data suggesting mitochondria as major determinants of cell fate, some still argue that the primary apoptosis signals relay directly to the caspases, and mitochondria only act as an amplifier. For instance, Cyt c release is delayed in casp $-3^{-/}$casp $-7^{-1-}$ DKO MEFs (mouse embryonic fibroblasts) (77), suggesting the existence of a feedback loop by caspases positively regulating the upstream events. In our opinion, this amplification loop actually further demonstrates the central role of mitochondria in apoptosis.

\section{REGULATION OF MITOCHONDRIA PERMEABILITY BY BCL-2 FAMILY PROTEINS}

The mitochondrial pathway acts in response to death stimuli including DNA damage, chemotherapeutic agents, serum starvation, and UV radiation. In certain cell types, the extrinsic pathway, initiated by cell surface receptors such as Fas, can cross talk with the intrinsic pathway through caspase- 8 mediated cleavage of Bid, resulting in truncated tBid that will translocate to mitochondria and trigger Cyt c release $(81,89)$.

Shortly after the discovery that the primary antiapoptotic function of Bcl-2 was to block Cyt $\mathrm{c}$ release, the central question was: How does Bcl-2 do this at the molecular level? It turns out there is a large family of Bcl-2 homologs that can be divided into two classes: antiapoptotic Bcl-2 family proteins (such as Bcl-XL, Bcl-w, Mcl-1, A1, Bcl-Rambo, BclL10, and Bcl-G) and proapoptotic proteins (such as Bax, Bak, and Bok) (21). A more heterogeneous group of proteins sharing a $\mathrm{BH} 3$ motif called the $\mathrm{BH} 3$ family of proteins (such as Puma, Noxa, Bid, Bad, Bim, Bik, Hrk, and Bmf) bind and inhibit the core antiapoptotic Bcl-2 proteins and hence act as proapoptotic proteins (152). The crucial role of $\mathrm{Bax} / \mathrm{Bak}$ in apoptosis induction was reflected by the extreme resistance of $\mathrm{bax}^{-/-} \mathrm{bak}^{-/-}$ DKO cells to a variety of apoptotic stimuli (135). It appears that BH3-only proteins and antiapoptotic Bcl-2 proteins are positive and negative regulators of Bax/Bak, respectively. Neither activation of BH3-only proteins nor suppression of prosurvival Bcl-2 proteins is sufficient to kill cells in the absence of both Bax and Bak (160), suggesting that Bax/Bak are the key regulatory targets where many intracellular signals converge and determine the fate of the cell.

In healthy cells, Bax is localized in the cytosol as a monomer. During apoptosis, Bax translocates to mitochondria $(54,140)$ and undergoes conformational changes to form oligomers (3), appearing as foci on mitochondria (Figure 2). In contrast, Bak constantly resides on mitochondria but does go through a series of conformational changes to oligomerize during apoptosis (45). Bax translocation and Cyt $\mathrm{c}$ release are regarded as two key upstream molecular events of apoptosis. Two models have been proposed regarding how BH3-only proteins activate Bax/Bak. The direct activation model states that Bax/Bak can be activated directly by Bim, Bid, and Puma or by other BH3-only proteins through 
releasing $\mathrm{Bim} / \mathrm{Bid} / \mathrm{Puma}$ from association with antiapoptotic Bcl-2 proteins (65). The indirect model proposes that $\mathrm{Bax} / \mathrm{Bak}$ become active when the antiapoptotic $\mathrm{Bcl}-2$ proteins are bound by BH3-only proteins (138). Although evidence exists for and against either model, both models are based on the direct interactions among the three groups of proteins, which are in many cases identified through overexpression or synthetic $\mathrm{BH} 3$ domain peptides or Co-IP in the presence of detergents. This is particularly problematic when growing evidence suggests that a lipid environment is required for effective interactions among those proteins (19). In an "embedding together" model, it was speculated that Bax/Bak go through multiple, regulated conformational changes before assuming a final conformation necessary for membrane permeabilization (78). There is equilibrium between different conformers, which can be affected by interactions with BH3-only proteins. Hence, both pro- and antiapoptotic Bcl-2 family proteins engage in similar dynamic interactions that are governed by membrane-dependent conformational changes. It was reported that the mitochondria-specific lipid, cardiolipin, provides specificity for targeting tBid to mitochondria (90). Cardiolipin also serves as an anchor and activation platform for caspase- 8 targeting and embedding in the mitochondrial membrane where it oligomerizes to be activated (41), indicating the importance of protein-lipid interaction. Recently, it was shown that tBid rapidly binds to the membrane in vitro, then interacts with Bax, which triggers Bax insertion into membrane and oligomerization, culminating in membrane permeabilization (87). However, it is still not clear how oligomeric Bax and Bak induce membrane permeabilization and Cyt $\mathrm{c}$ release.

It was initially thought that mitochondrial membrane permeability might originate from a sudden increase in the permeability of the inner membrane to low molecular mass solutes because of the opening of a multiprotein pore PTP at the contact site between the outer membrane and inner membrane (38). The exact molecular composition of this complex is not clear and assumed to contain hexokinase, voltage-dependent anion channel (VDAC, on the outer membrane), the adenine nucleotide translocase (ANT, in the inner membrane), and cyclophilin D (CypD, a peptidyl-prolyl isomerase in the matrix). Opening of PTP leads to matrix swelling, depolarization of the membrane potential (dissipation of the $\Delta \psi \mathrm{m}$ built across the inner membrane), subsequent rupture of the outer membrane, and nonselective release of IMS (intermembrane space) proteins. Although some biochemical data and studies with pharmacological inhibitors support a role of PTP (73), growing evidence, especially genetic analysis, suggests that PTP opening is likely a consequence of apoptosis. For example, VDAC1/VDAC2/VDAC3 triple KO mice display normal apoptosis without changes in PTP opening (8) (Table 1). Cells deficient in cyclophilin-D die normally after apoptotic treatment but show resistance to necrotic cell death $(7,98)$. Moreover, ANT KO mice have normal PTP (71). Also, Cyt c release occurs in the absence of mitochondria depolarization and without loss of outer membrane integrity (146).

Three-dimensional structures of the Bcl-2 proteins (both anti- and proapoptotic proteins such as $\mathrm{Bcl}-\mathrm{xL}, \mathrm{Bax})$ resemble that of bacteria toxins, proteins that can punch holes in the membranes to kill cells (96). The consensus now is that Bax oligomerization is required for Cyt c release (31). In cell-free systems, Bax, Bid, and lipids cooperate to form supramolecular openings (allow passage of up to 2000-kDa molecules) in the outer mitochondrial membrane (76), which can be directly inhibited by Bcl-xL. Such large 
openings shall allow release of all soluble IMS proteins without any selective preference. Mitochondrial apoptosisinduced channel (MAC) was also proposed to be responsible for release of IMS proteins (67), which contain Bax and Bak as the putative components. Nonetheless, the biochemical nature of either MAC or oligomeric Bax/Bak-induced pores remains unknown. Irrespective of the nature of the permeability, a series of proteins is released from mitochondria during apoptosis as discussed below, which are essential for proper execution of apoptosis.

\section{Cytochrome c}

Cytochrome $\mathrm{c}(\mathrm{Cyt} \mathrm{c})$ is an essential component of the mitochondrial electron transport chain. It is translated as apocytochrome $\mathrm{c}$ and then translocated into the mitochondrial IMS. Once inside the IMS, a heme group is attached to form the holocytochrome $\mathrm{c}$. It is the heme moiety that acts as a redox intermediate to shuttle electrons between complex III (Cyt b-c1 complex) and complex IV (Cyt c oxidase complex).

When mitochondria were suggested to be required for apoptosis (99), no one expected Cyt c would play a pivotal role until it was identified as one of the three apoptotic protease activating factors (Apafs) for caspase activation by Xiaodong Wang's group (86). It led to the finding that many other IMS proteins are also released from mitochondria during apoptosis (see below).

Although originally greeted with skepticism, the role of Cyt $\mathrm{c}$ in apoptosis has been established both biochemically and genetically. First, purified Cyt c can trigger caspase activity in a cell-free system using extracts from healthy nonapoptotic cells (86). Second, in vitro apoptosome activity has been reconstituted with recombinant Cyt c, Apaf-1, and caspase-9 proteins in the presence of ATP/dATP (84). Cyt c deficient mice are embryonic lethal owing to Cyt c's indispensable role in mitochondria electron transport chain. Nonetheless, $c y t c^{-1-}$ MEFs exhibit resistance to a variety of apoptotic stimuli (82). Later, a knockin mouse model was made with Cyt c K72A (49) (Table 1). The Cyt c K72A (KA) mutation largely abolishes the interaction with its receptor, Apaf-1, and hence reduces caspase-3 activity by tenfold in vitro, whereas it remains fully functional in shuttling electrons in the mitochondria respiration chain. KA mice were born at a frequency of $12 \%$, with developmental defects apparent in KA/KA embryonic brains, displaying ectopic masses with exencephalic defects and expansions of the cortex and midbrain. The exencephalic phenotype of postnatal day $1 \mathrm{KA} / \mathrm{KA}$ mice recapitulates that of apaf-1 $1^{-/}$and casp $-9^{-/-}$mice $(15,47,75,150)$, strongly indicating that Cyt $\mathrm{c}$ acts in the same pathway. Like $\mathrm{bim}^{-/-}$and $\mathrm{bax}^{-/-} \mathrm{bak}^{-/-}$DKO $(11,85)$, KA mice also exhibit splenomegaly and lymphadenopathy. Normal Cyt c release and respiratory function were found in KA mice, but caspase activation is impaired, and Apaf-1 oligomerization was not observed in response to UV or staurosporine (STS) treatment. However, thymocytes from KA mice were normally sensitive to dexamethasone, etoposide, and gamma and UV radiation, whereas apaf $-1^{-1-}$ thymocytes exhibited a partial resistance to all of these stimuli. One possibility is that the Cyt c K72A mutant is still capable of activating caspase-3 in thymocytes. However, Apaf-1 oligomerization remains impaired in KA thymocytes, suggesting the existence of apoptosome-independent pathways of caspase activation. This is consistent with the 
observation that $\mathrm{Bcl}-2$ overexpression increased lymphocyte numbers in mice and inhibited many apoptotic stimuli to a greater extent than seen in apaf- $1^{-/-}$or casp $^{-9^{-/-}}$KO mice (91).

Soon after identification of Apaf-1, it was found that Apaf-1 and Casp-9 form a large complex in the presence of Cyt $\mathrm{c}$ and dATP (84). Based on crystal structures of both Apaf-1 alone and the apoptosome complex, it seems that the nonactive Apaf-1 protein may exist in a compact and closed form, probably through intramolecular interaction with the $\mathrm{N}$-terminal CARD domain sandwiched in the lobes of the C-terminal WD40 repeats (9). Hence, the buried CARD domain is not accessible to procaspase-9. Deletion of this WD40 domain results in Apaf-1 constitutively binding and activating caspase-9, indicating that the Apaf-1 monomer is in an auto-inhibited state $(9,55)$. Upon Cyt c binding to the WD40 region, the CARD domain is displaced, leading to an open conformation. Then, ATP/dATP bound to the nucleotide-binding domain undergoes hydrolysis to induce conformational changes (66), creating a less flexible, locked form. The Apaf-1 in this new conformation coassembles with six other subunits to form a symmetric wheel-shaped structure, a platform ready to recruit procaspase-9 to form the active apoptosome (116).

Apparently, Cyt $\mathrm{c}$ is at the heart of Apaf-1-mediated caspase activation and thus, the regulation of Cyt $\mathrm{c}$ release is vital in the tightly regulated intrinsic apoptosis pathway. Given that the majority of Cyt $\mathrm{c}$ resides inside the narrow cristae junctions, it was speculated that release of Cyt $\mathrm{c}$ requires two steps: mobilization and translocation where the mobilization step might involve cristae remodeling (114). During mobilization, Cyt c detaches from the inner mitochondria membrane (IMM) and dissociates from the membrane phospholipid cardiolipin (102). However, it is not clear how Cyt $\mathrm{c}$ detaches from the IMM and how important cardiolipin is in retaining Cyt c.

It has long been reported that mitochondrial fission machinery actively participates in the process of apoptosis (151), and the topic of mitochondrial dynamics and apoptosis has been recently reviewed (121). Since then, new discoveries have shed fresh light on how Cyt $\mathrm{c}$ is released after oligomerized Bax/Bak-induced outer membrane permeability. It was originally thought that cristae junctions must become wider to allow passage of Cyt $\mathrm{c}$ from the intracristae space into the intermembrane space given that more than $85 \%$ Cyt $\mathrm{c}$ resides within cristae. Indeed, it was shown that cristae junctions became wider during apoptosis and are independent of Bak (114). However, the hole of cristae junctions in normal mitochondria is big enough to allow $60-100 \mathrm{kD}$ proteins to go through (67), suggesting that it would be unnecessary to widen the cristae junctions. Several reports have reported that Cyt c release occurred prior to large-scale cristae remodeling, which is actually caspasedependent (indicating it takes place at a later stage of apoptosis) $(122,143)$. Moreover, a recent report found that cristae junctions became narrower instead of wider during apoptosis (142). It was proposed that the width of cristae junctions was regulated by the Opa1 protein, a protein involved in mitochondrial fusion (35). When Opa1 assembles into a larger complex, the cristae junctions are wider and in a closed state. When Opa1 disassembles, the junctions become narrower but are in an open state to allow increased availability of Cyt $\mathrm{c}$ at the outer membrane (142). In support of this, a mutant Opa1Q297V (which is disassembly resistant) can protect cells from cell death by preventing Cyt $\mathrm{c}$ release (and the release of other IMS proteins such as Smac and Omi) without affecting Bax activation (142). To verify 
the importance of this inhibition on Cyt c release under physiological condition, a knockin mouse model with Opa1Q297V mutation would be useful for comparison with Cyt c KA mice regarding resistance to apoptosis to clarify whether Opa1 disassembly plays a vital role in controlling Cyt c release. Consistently, the mitochondrial fission protein Drp1 was also reported to be involved in cristae remodeling (40). In addition, knockdown of Drp1, although not affecting Bax activation, inhibited Cyt c release but not Smac release (79, 104, 33). This is different from Opa1Q297V-mediated inhibition of Cyt c release (as the latter also inhibits Smac release). However, it remains possible that Drp1 acts through Opa1, and epistasis experiments between these two proteins in controlling Cyt $\mathrm{c}$ release await to be performed.

\section{Smac/DIABLO}

Smac was identified by its ability to enhance Cyt c-mediated caspase-3 activation (27). Vaux's lab independently identified the same protein, which they named DIABLO, through Co-IP with XIAP (132). Apparently, Smac/DIABLO facilitates caspase activation by binding to XIAP (and other IAPs such as cIAP1 and cIAP2) and hence, relieves caspases (both caspase-9 and caspase-3) from inhibitory effects of IAPs (119). It turn out that XIAP cannot bind and inhibit procaspase-9, but instead sequesters or triggers the proteolytic processing of mature caspase-9. Therefore, Smac could compete with mature caspase- 9 for interaction with XIAP (as the binding is mutually exclusive) and lead to the release of mature caspase-9 from the grip of XIAP (120). On the other hand, XIAP can polyubiquitinate both mature caspase- 9 and Smac (95), indicating the battle between these factors may decide whether cells will die.

However, some intriguing observations bring more complexity to the mechanisms underlying Smac function. First, it was found that XIAP mutants that are defective in caspase-3 inhibition but retain Smac- and caspase-9 binding were still cytoprotective (117). Other studies reported similar results with different IAPs, indicating that IAPs can suppress cell death through caspase inhibition and inhibition of Smac (28). However, it is unclear if these IAPs mutants can still bind caspase-7 or Omi/HtrA2. Second, Smac beta, a splicing variant that lacks the mitochondria targeting sequences and does not bind IAPs, can still sensitize cells to apoptosis (109), suggesting that Smac could function other than solely as IAPs' antagonist. Third, another splicing variant, Smac3 [missing 44 residues right after the IAP-binding motif (IBM) of Smac], acts similar to Smac, but can trigger XIAP autoubiquitination and destruction (36). Finally, the physiological role of Smac in apoptosis was brought into doubt by the normal phenotype of Smac KO mice (100) (Table 1).

However, more detailed characterization of the Smac KO mice is required to make sure other splicing variants or potential truncated proteins are not produced in the KO mice. This is particularly important as a previous study has implied that Smac may function other than binding IAP through the C-terminal domain. Another possibility why the Smac KO mice fail to show any antiapoptotic phenotype could be simply owing to redundancy of other proteins. In support of this, in vitro caspase- 3 activation is impaired in Smac KO lysates, whereas in vivo caspase- 3 can be normally processed in KO MEFs or other cell types. Nonetheless, $\mathrm{Smac}^{-/-}$HCT116 cells are resistant to certain apoptotic stimuli and, interestingly, Cyt $\mathrm{c}$ and AIF release are delayed in these KO cells (70) (Table 1). 
Like Cyt c, the release of Smac is caspase-independent (108). In agreement, Zhou et al. reported that Smac and Cyt c release proceeds in the same narrow window (5-6 min) (159). However, fibroblast growth factor FGF-2 can block Smac but not Cyt c release in etoposide treated SCLC cells (103). Activation of JNK induces generation of a novel Bid cleaved fragment $\mathrm{jBid}$, which translocates to mitochondria and triggers Smac but not Cyt $\mathrm{c}$ release (25). Smac then disrupts the TRAF2-cIAP1 complex to trigger Cyt c-independent cell death. Consistently, overexpression of $\operatorname{Bid} \Delta 25$, which mimics jBid, induces Smac release but not Cyt c. This is another example of how the extrinsic and intrinsic pathways are interconnected. On the other hand, Drp1 inhibition prevents Cyt c release more than Smac release (104). These examples of selective release of IMS proteins argue against the nonselective model of Bax/Bak-induced MOMP or indicate the existence of an additional regulation level beyond the supramolecular openings.

As growing evidence suggests a downstream feedback amplification loop of caspases on mitochondria dysfunction, it is not surprising that overexpression of Smac can lead to Baxand Bcl-xl independent but caspase-dependent cell death with Cyt $\mathrm{c}$ release occurring at a late stage of apoptosis (50). Most intriguing is that Smac is not released from mitochondria in Cyt c KO MEFs cells during apoptosis (48). These MEFs are resistant to STS, UV radiation, and serum starvation. Bax translocation and activation occur normally in Cyt $\mathrm{c}$ $\mathrm{KO}$ cells. It's not clear if Bax oligomerization can still occur or if MOMP is affected in Cyt c KO cells, and it would be interesting to examine Smac release in Cyt c KA knockin cells. However, the data are consistent with the report that caspase-3 and -7 DKO cells fail to release Cyt c (77).

\section{Omi/HtrA2}

Omi was originally identified as a human homolog of the bacterial HtrA2 (high temperature requirement A) gene that interacts with Mxi2 (32). Later, HtrA2/Omi was independently identified by three groups as a novel XIAP-binding protein $(51,92,125)$ and as an additional proapoptotic protein released from mitochondria into the cytosol by tBid treatment (130). Omi/HtrA2 transports into mitochondria as a precursor protein with the Nterminus exposed to the matrix and the majority of the $\mathrm{C}$-terminus containing the protease domain facing the intermembrane space. A transmembrane domain near the $\mathrm{N}$-terminus tethers Omi/HtrA2 to the inner membrane followed by an IBM which will be exposed in the IMS after processing by an unknown mitochondrial protease(s) at residue 133 (131). Interestingly, more than half of the Omi protein remains unprocessed in mouse liver, whereas most Omi/HtrA2 is processed in heart tissue and in 293 cells (60).

It has been proposed that, unlike Smac/DIABLO, Omi/HtrA2 can irreversibly degrade IAP through its protease activity in addition to sequestering IAPs through IBM binding. IBMdeficient mutants cleave recombinant cIAP1 10 times less efficiently than the wild-type Omi (147). Contradictory data have been reported regarding whether overexpression of Omi/ HtrA2 triggers apoptosis. On the one hand, it was shown that extramitochondrially expressed Omi/HtrA2 only induced atypical cell death whereas protease-inactive mutant Omi/HtrA2 lost cell-killing activity. The atypical cell death was not inhibited by XIAP or z$\mathrm{VAD}$, indicating it is caspase-independent (125). On the other hand, it was reported that 
knockdown of Omi leads to resistance of cells to apoptosis, whereas overexpression of Omi enhances apoptosis (51). Both protease activity and IAP-binding activity of Omi/HtA2 are required for killing, although via caspase-independent and -dependent pathways, respectively.

However, both naturally occurring Omi/HtrA2 mutant mice and gene targeting mice failed to show any expected apoptotic phenotype and actually showed the opposite, excessive apoptosis (Table 1). In mnd2 mice, a S276C mutation in Omi almost abolishes all protease activity. The $m n d 2$ mutant mice exhibit muscle wasting and neurodegeneration, and die by 40 days after birth. Degenerating neurons in the mutant mice display mixed features of necrosis and apoptosis. In addition, $m n d 2 \mathrm{MEFs}$ are more sensitive to apoptosis (60). In gene targeted Omi KO mice, similar defects were observed such as weight loss, smaller organ size, and striatal neuron loss. KO mouse cells exhibit increased sensitivity to cell death (including fibroblasts and lymphocytes) (93). Does Smac compensate for Omi's function in the KO cells? $\mathrm{smac}^{-/-} \mathrm{omi}^{-/-}$DKO mice display a phenotype similar to that of Omi KO mice, and the DKO cells are more sensitive to etoposide (93). The structural similarity between Omi and bacterial HtrA suggests that Omi may be a sensor of unfolding stresses in the mitochondria. Loss of Omi may lead to accumulation of misfolded and damaged proteins, and mitochondrial dysfunction. Hence, the role of Omi/HtrA2 in normal mitochondrial maintenance might mask its apoptotic function in these mutant mice given that the two functions could counteract each other. A better approach might be to generate a knockin mouse model with a mutation that blocks its release from mitochondria.

Moreover, the role of IAPs in mammalian apoptosis has been brought into question. Although Omi/HtrA2 can bind and degrade cIAP1, cIAP2, and XIAP in vitro, XIAP seems to be the only bona fide inhibitor of caspase-3, -7 , and -9 (29). Nonetheless, XIAP-deficient mice lack a clear apoptotic phenotype, owing to either redundant roles of cIAP1 and 2 or a limited physiological role for IAPs in the control of apoptosis (131). In addition, two IAPlike proteins in C. elegans do not seem to be implicated in apoptosis (131). Apparently, any apoptotic function of Omi/HtrA2 would depend on how much IAPs contribute to the overall apoptotic response of tested cells.

\section{EndoG}

The name of endonuclease $\mathrm{G}$ was derived from its nuclease activity that nicks DNA and RNA (88). EndoG belongs to the large family of DNA/RNA nonspecific $\beta \beta a-M e-f i n g e r$ nucleases (113) and has long been studied with different names including mitochondrial DNA (RNA) 5'-endonuclease, sugar nonspecific mitochondrial nuclease, mitochondrial nuclease (NUC1), and mitochondrial endo-exonuclease (88).

Recently, interest shifted to the role of en-doG in apoptosis with the discovery that en-doG appears to be released from mitochondria to facilitate the degradation of nuclear chromatin (83). How endoG is released and whether the release is dependent on caspase activity are still under debate. Li et al. first showed that the release of endoG is independent of caspase activity as tBid alone in the presence of $\mathrm{z}-\mathrm{VAD}$ can still trigger endoG release from isolated mitochondria (83). However, Arnoult et al. clearly showed that endoG cannot be released from isolated Hela mitochondria treated with oligomerized Bax or tBid (6). In vivo, the 
release of endoG from mitochondria is strongly inhibited by z-VAD or in apaf-1 $1^{-/-}$MEF cells indicated by both immunofluorescence staining and Western blotting. Consistently, they found that endoG mainly resides in the mitochondrial inner membrane and matrix. This suggests that the endoG release is distinct from that of $\mathrm{Cyt} \mathrm{c}$, and requires further processing (as with AIF) or additional mitochondria inner membrane remodeling during apoptosis.

Once released from mitochondria, the function of endoG is no longer dependent on caspase activity. Overexpression of cytosolic endoG (without mitochondria localization signal) promotes cell death characterized with nuclear DNA fragmentation in Hela or CV1 cells (113). Widlak et al. reported that exonuclease and DNase I can cooperate with endoG in inducing cell death (137). However, genetic data do not support an essential role of endoG in apoptosis.

Two groups independently generated endoG $\mathrm{KO}$ mice and showed that the $\mathrm{KO}$ mice are viable and display no developmental defects (Table 1) $(22,58)$. MEF cells from endo $G^{-/}$mice are as sensitive to apoptosis as wild-type MEFs. As a consequence, Ekert \& Vaux called for acquitting the role of endoG in apoptosis (30).

\section{AIF}

AIF (apoptosis inducing factor) was the second protein found to be released from mitochondria during apoptosis (124). AIF is a flavin-adenine dinucleotide (FAD)-binding oxidoreductase, but neither its FAD-binding ability nor its oxidoreductase activity is required for its apoptotic function (123).

AIF is a type-I inner mitochondrial membrane protein with the N-terminus facing the matrix and the C-terminal portion residing in the IMS. During apoptosis, a proteolytic processing takes place at L101/G102 to produce a soluble AIF protein. Mutations or deletions that block this processing prevent AIF release. Consistent with this tethering, Arnoult et al. found that caspase inhibitor z-VAD blocks AIF release from mitochondria both in vivo and in vitro (6). However, how caspases are involved in triggering AIF release is not clear. Later, several other reports challenged this report by showing that AIF release is caspaseindependent. The difference might be due to the concentration of $\mathrm{z}$-VAD being used. Whereas higher doses of z-VAD $(100 \mu \mathrm{M})$ can lead to nonspecific inhibition of other cysteine proteases that may be involved in AIF processing (155), lower doses of z-VAD may not be enough to completely block caspase activity.

After cleaved AIF (also called tAIF) is released from mitochondria, the NLS motif in the protein allows it to translocate to the nucleus where it interacts with DNA and leads to chromatin condensation and DNA degradation into $50 \mathrm{~kb}$ fragments (148). DNA-binding defective AIF mutants are still capable of translocating to the nucleus but fail to induce cell death. It remains a mystery how AIF can degrade DNA as it does not have any intrinsic endonuclease properties. One possibility is that AIF can recruit downstream nucleases such as endoG (12).

Although AIF has been extensively studied over the past decade, whether AIF plays an essential role in apoptosis under physiological conditions remains debated. The initial 
assignment of the role of AIF in apoptosis largely derives from in vitro and overexpression studies, but profound apoptogenic activity of AIF has never been verified in vivo under physiological conditions.

First, Joza et al. reported that AIF deficient male ES cells (AIF ${ }^{-/ y}$, AIF is on the X chromosome) are impaired in embryo cavitation, as sensitive to many apoptotic stimuli as wild-type cells, and only exhibit some resistance to serum withdrawal-induced cell death (62). However, using a conditional gene targeting approach, both Joza and Brown et al. showed that AIF deficient embryos could still form a proaniotic cavity $(13,61)$ (Table 1$)$. In addition, Brown et al. argued that the failure of $\mathrm{AIF}^{-/ y} \mathrm{ES}$ cells to generate chimeric mice is largely due to the essential role of AIF in maintaining normal mitochondrial respiration through its oxidoreductase activity.

Harlequin (Hq) mutant mice exhibit ataxia and loss of cerebellar neurons, caused by proviral insertion into the AIF gene resulting in an $80 \%$ reduction in AIF protein. Klein et al. showed that mutant cerebellar granule cells from these mice are susceptible to oxidativestress induced apoptosis (68). Hq mice also exhibit partial complex I deficiency, optic tract dysfunction, and retinitis pigmentosa, all typical features of mitochondrial disease (10).

Recently, studies with muscle- and liver-specific conditional AIF KO mice indicated that the primary physiological role of AIF is to maintain a fully functional respiratory chain (106). Furthermore, human colon cancer cell lines HCT116 and DLD-1 are both derived from males and $\mathrm{AIF}^{-/ y}$ cancer cells are more sensitive to DNA damage agents and oxidative stress than wild-type cells but exhibit normal response to STS and actinomycin D. All these phenotypes can only be rescued by introduction of AIF that still contains NADH oxidoreductase activity (Table 1) (128).

Finally, Cheung et al. generated telencephalon conditional $\mathrm{AIF}^{-/-}$mice and showed that AIF is required for neuronal cell survival and normal mitochondrial respiration in neurons (18). By analyzing mitochondrial inner membrane-anchored AIF mutants (which cannot be cleaved and released during apoptosis), they showed that mitochondrial function of AIF is responsible for Tel. $\mathrm{AIF}^{-/-}$phenotype (cell death and mitochondria dysfunction). Nonetheless, AIF seems to provide limited though significant protection from apoptosis in their experimental settings. Given the essential role of AIF in normal mitochondria function, to unambiguously define the role of AIF in apoptosis, one needs to make a cleavageresistant AIF mutation and hence one that cannot be released during apoptosis so that its apoptogenic function is blocked, whereas its oxidoreductase activity remains intact.

\section{THE ROLE OF MITOCHONDRIA IN INVERTEBRATE CELL DEATH}

Given that key regulators of apoptosis (such as Bcl-2, Apaf-1, and caspases) were found highly conserved across metazoan species, it was reasonable to expect an evolutionary conservation of cell death mechanisms from worms to humans. A common downstream event is the activation of caspase proteases, which, by cleaving a large variety of cellular substrates, initiates many coordinated processes to dismantle cells without triggering inflammatory processes. Whereas it is not surprising that the basic machinery of apoptosis becomes more elaborate and diversified in mammals than in worms, the seeming lack of 
involvement of mitochondria in the activation of caspases in invertebrates is surprising (Figure 1). There are many controversial data regarding whether or not Cyt c plays any vital role in fly apoptosis. On the one hand, the essential role of mitochondria in the regulation of caspase activity might have evolved separately in vertebrates. On the other hand, some unknown reasons may currently prevent us from revealing the pivotal role of mitochondria in invertebrate apoptosis. We focus on two major invertebrate model species below, trying to understand whether and why such a link is missing.

\section{C. elegans}

Genetic analysis has firmly established a linear pathway with Egl-1, Ced-9, Ced-4, and Ced-3 as the core executioners of worm cell death. Almost all somatic cell death is blocked in loss-of-function $e g l-1$, ced-4, and ced-3 null mutants or gain-of-function ced-9 mutants (80). As in mammals, activation of caspases (Ced-3) in worms also involves a so-called apoptosome formation even though the complex is much simpler. Genetic and biochemical analyses illustrate a straightforward model for Ced-3 activation. A protein distantly related to Apaf-1, Ced-4 is constantly bound by the Bcl-2 homolog Ced-9 (2:1 complex) in live cells. An apoptotic signal upregulates the BH3-only protein Egl-1, which binds Ced-9 to induce significant conformational changes such that Ced-9 dissociates from Ced-4. The freed Ced-4 dimers complex to form a Ced-4 apoptosome (tetramer), which facilitates the autoactivation of Ced-3 $(116,145)$. Although how the tetrameric Ced-4 activates Ced-3 remains unclear, two structural differences might account for the lack of Cyt $\mathrm{c}$ involvement in Ced-3 activation. First, Ced-4 protein does not contain a WD40 repeat domain, which is present in mammalian Apaf-1 protein and has been shown to be the binding site for Cyt $\mathrm{c}$. Second, the WD40 domain interacting with the CARD domain keeps Apaf-1 monomeric in an auto-inhibition form. In contrast, Ced-4 is simply bound by Ced-9 to prevent its oligomerization and access to Ced-3. In vitro, Ced-3 activation can occur with just the addition of Ced-4 (144). Why Ced-9 is localized on the mitochondrial outer membrane is not clear as it was recently shown that the mitochondria localization of Ced-9 is not required for interaction between Ced-9 and Ced-4 (126). Both Ced-9 without the transmembrane domain and Ced-9 artificially tethered to the cytosolic surface of ER can rescue the phenotype of ced-9 mutants (126). Therefore, localization of Ced-9 on mitochondria may be required for alternate nonapoptotic functions.

As with mammalian endoG, its homolog in C. elegans, Cps-6 (Ced-3 protease suppressor), was identified through a sensitized genetic screen with a phenotype of delayed progression of apoptosis (105). csp-6 alone exhibits an undetectable apoptotic defect but can enhance weak ced-3 or ced-4 phenotypes, suggesting either a minor role of Csp-6 or the existence of redundant genes. However, it was not shown if Csp-6 is released from mitochondria during apoptosis. C. elegans also contains an AIF homolog, Wah-1 (worm AIF homolog). wah-1 RNAi worms exhibit slower growth rates, smaller brood sizes and delayed cell corpse appearance (134). Wah-1 can cooperate with Cps-6 to efficiently degrade DNA and synergize with Cps-6 to induce cell killing when coexpressed. Although Wah-1 is released from mitochondria induced by EGL-1 (134), it is not clear how it is released. Interestingly, WAH-1 was also shown to be involved in phosphatidylserine (PS) externalization (133), 
consistent with the previous observation that overexpression of AIF promotes surface PS exposure (123).

As shown above, there is little evidence for an essential role of mitochondria in induction of C. elegans cell death. However, research in the worm focuses on developmental cell death while pathogen-stimulated or genotoxic stress-induced apoptosis might utilize distinct mechanisms. For instance, it was recently found that ceramide biogenesis is required for radiation-induced apoptosis in the germ line of C. elegans (24). In addition, a new layer of regulation of apoptosis was recently revealed, indicating that worms, although containing no IAP-like homologs in the genome, do have other inhibitors of caspases. Csp-3, one of the three additional caspase-like genes in worms, does not contain a large subunit and shares homology with the small subunit of Ced-3. Hence, Csp-3 can bind to the large subunit of Ced-3 and inhibit autoactivation of Ced-3 (39). This acts as a safeguard mechanism to prevent inadvertent Ced-3 autoactivation in cells that normally live. During apoptosis, Ced-4 oligomers can override Csp-3 inhibition by either competing for Ced-3 binding or inducing Ced-3 conformational changes to reduce Csp-3 binding. However, loss of Csp-3 only results in a weak apoptotic phenotype, indicating the existence of redundant genes or a minor role of this kind of inhibition in normal development. Nonetheless, owing to the lack of IAPs, it is not surprising that no Smac or Omi/HtrA2 homologs have been found in C. elegans.

In Drosophila, caspase activation is also the core of regulation of apoptosis (149) indicated by the abolishment of almost all cell death during embryogenesis in the H99 deletion flies (136), which is due to the concomitant loss of Reaper, Hid, and Grim genes (collectively called RHG proteins). RHG proteins interact with Drosophila IAPs (mainly the DIAP-1) and promote DIAP-1 auto-ubiquitination and degradation and hence, prevent DIAP-1 from ubiquitinating and degrading initiator caspase Dronc $(16,43,139,149)$. Overexpression of any one of the RHG genes triggers excessive cell death, indicating that the removal of IAP is sufficient to induce caspase activation and the demise of cells. Consistently, DIAP1 deficiency leads to spontaneous apoptosis in most fly cells $(43,149)$. These data led to the concept that Drosophila caspases might not require activation, but simply relief from potent inhibitors of caspases. However, in healthy cells, Dark, the Apaf-1 homolog, exists as a monomer, which is believed to be inactive. It was also shown that unrestrained cell death caused by loss of DIAP1 required the Apaf-1 homolog Dark (110), suggesting that caspasedependent cell death involves concurrent positive input together with removal of IAP's inhibition. It also suggests that RHG proteins may promote caspase activation through mechanisms other than merely antagonizing DIAP1.

Indeed, it was recently reported that Reaper and Hid rapidly permeabilize mitochondria and release Cyt c in S2 cells (1). One caveat is that the release of Cyt $\mathrm{c}$ can only be detected by immunostaining and not by subcellular fractionation and the release itself is not responsible for Reaper and Hid-induced apoptosis (1). In addition, actinomycin D or UV failed to trigger Cyt $\mathrm{c}$ release even though caspase activity was high. Mitochondria targeting of RHG proteins seems to be required for their functions given that Reaper $\Delta \mathrm{GH} 3$ or Grim $\Delta \mathrm{GH} 3$, which no longer bind mitochondria, failed to induce apoptosis $(20,101)$. In addition, 
membrane localization per se contributes to DIAP1 degradation as colocalization of DIAP1 and Reaper at a membrane surface is critical $(34,101)$. Surprisingly, RHG proteins are capable of targeting to mitochondria and inducing Cyt c release in mammalian cells $(20,34$, 46), which is Bax/Bak-independent.

The hunt for a role of Cyt $\mathrm{c}$ in fly apoptosis is partly due to the belief of conservation of cell death mechanisms and partly due to the fact that the Drosophila Apaf-1 homolog Dark also contains WD40 repeats in the C-terminus, which have been shown to be the Cyt c-binding site in Apaf-1. In addition, fly Cyt c can functionally substitute for human Cyt $\mathrm{c}$ in reconstitution of apoptosome activity in mammalian cells (111).

In the absence of added dATP/ATP, incubation of Dark with Dronc results in immediate formation of the apoptosome. It consists of two wheel-shaped particles assembled face to face, each involving eight molecules of Dark. Dark may merely function as a scaffold to bind Dronc and facilitate its maturation through autocatalytic cleavages (153). The CARD domain of Dronc is removed in the mature caspase (97), suggesting a mode of activation different from that of caspase-9. Unfortunately, reconstitution of a functional apoptosome complex with purified recombinant proteins has not been reported.

Therefore, it is not surprising that there is predominant evidence against the involvement of Cyt $\mathrm{c}$ in caspase activation both in vitro and in vivo in responding to a variety of stimuli (26). However, strong evidence for the involvement of Cyt c came from the discovery that cyt-c-d is necessary for effector caspase activation and spermatogenesis $(4,5)$. It was also found that cyt-c-d regulates developmental apoptosis in the fly retina (94). However, as it was not shown if the apoptotic phenotype in the eyes depends on Dronc or Dark, it may be possible that the lack of caspase activation could be due to reduced ATP level or dysfunctional mitochondria in $c y t-c-d^{-/}$flies. Later, it was found that the $c y t-c-d$ mutants used in the above-mentioned studies contain a P-element that also disrupts two other genes (56). Furthermore, Drice activation during spermatogenesis appears to be Dark- and Droncindependent (56), raising the possibility that the defects shown in $c y t-c-d$ mutants could be simply due to mitochondria dysfunction-mediated cell death.

It is also puzzling that the only two Bcl-2 homologs in flies, Debcl/Drob-1/dBorg- $1 / \mathrm{dBok}$ and Buffy/dBorg-2, seem not to play any role in developmental cell death when analyzed in either single or double knockout flies (115), which is in contrast to the data from RNAi and overexpression studies $(57,107)$. However, debcl $l^{w 105}$ flies are as resistant to $\gamma$-irradiation as $\operatorname{ark}^{\mathrm{CD} 4}$ (115), a mutant that almost fully lacks irradiation-induced apoptosis in the embryo (110). In contrast, loss of Buffy resulted in a small increase in irradiation-induced apoptotic cells. debcl buffy double mutants exhibit a phenotype similar to that of buffy single mutant flies, suggesting that Buffy acts antiapoptotically and downstream of Debcl (115). Although surprising, it suggests that both proteins are not essential for apoptosis induction and may exert their functions by regulating or interfering with the core apoptosis machinery in the flies. Recently, another report suggested that Debcl is not required for genotoxic stressinduced apoptosis and killing by RHG proteins, but is required for killing by Bax (37). 
Although it is not clear whether Bcl-2 homolog proteins play any essential roles in fly apoptosis, they do induce apoptosis in mammalian cells. dBok/Debcl induces apoptosis in human cells, which can be suppressed by human Bcl-2 family proteins (157). Even though $\mathrm{dBok} /$ Debcl targets to mitochondria and triggers Cyt c release in human cells, the BH3 domain is not required for its apoptotic function, similar to human Bok. In addition, ecotopic expression of Bcl-2 can suppress Reaper-induced apoptosis in Drosophila (14). Taken together, it seems that $\mathrm{Bcl}-2$ proteins, through association with mitochondria, have the potential to be involved in apoptosis in flies, but flies somehow have evolved a pathway that bypasses the usage of Bcl-2 proteins. It might be largely due to the fact that RHG proteins, the potent DIAP-1 antagonists, are transcriptionally regulated and do not need the control of Bcl-2 proteins on mitochondrial membrane permeability to regulate the release of IAP antagonists (such as Smac, Omi) in mammals. Another possibility is that unlike in mammals, where XIAP simply binds and inhibits the catalytic activity of caspase-9, fly DIAP-1 triggers Dronc degradation. By promoting DIAP1 degradation, induction of RHG proteins will ensure no more interference of DIAP1 on Dronc and Drice. These two caspases, just as procaspase-9, may have some weak catalytic activity as procaspases, which may be enough to induce apoptosis. Nonetheless, mitochondria seem to play greater roles in fly apoptosis beyond those regulated by Bcl-2 proteins. To support this, the mitochondrial fission protein Drp1 was found to participate in fly apoptosis as $d r p-1$ mutant hemocytes were protected from apoptosis induced by a variety of stimuli such as etoposide, actinomycin D, and UV-B radiation (42), in addition to exhibiting elongated mitochondria.

\section{Perspective}

Although the central role of mitochondria in apoptosis is well established in mammals, it remains largely unclear whether mitochondria are involved in apoptosis in other model systems such as nematodes and flies. It also raises a question about when mitochondria evolved to be central executioners of apoptosis. Given the functional conservation between worm Ced-9 and mammalian Bcl-2, why Drosophila Bcl-2 homologs seem not to play similar essential roles in apoptosis induction is mysterious. One puzzle is that many core apoptotic proteins are localized on the mitochondrial outer membrane such as Ced-9 in worms and RHG proteins in flies. Are mitochondria simply providing a membrane environment for protein-protein interactions as in the case of Bax and tBid interaction in mammals? In addition, when did vertebrates evolve extrinsic and intrinsic apoptotic pathways? Answers to these questions will help us to better understand how Bcl-2 family members act on mitochondria. One hypothesis for a housekeeping function of Bcl-2 family members is to regulate mitochondrial fusion and fission $(23,63)$.

It has been more than a decade since the central role of Cyt $\mathrm{c}$ in mitochondrial pathway has been discovered. However, key issues regarding how Cyt $\mathrm{c}$ is released from mitochondria remain largely unclear. In addition, models derived from biochemical data are often challenged by genetic analyses. It is worth mentioning that, whereas overexpression studies and in vitro biochemical work may inadvertently result in some artifacts, lack of apoptotic phenotypes in gene knockout mice or cell lines does not necessarily argue against a physiological role of the target genes. This is because gene redundancy and compensatory mechanisms could simply prevent the appearance of predicted phenotypes. In addition, 
alternative splicing variants could be responsible for lack of phenotype when only one splicing variant is inadvertently targeted for deletion. Therefore, careful characterization of knockout mice at the molecular level is desired. For instance, antibodies raised with defined epitopes (from both N-terminal and C-terminal regions of the target protein) will ensure that no truncated protein products (which might be functional) are produced in the knockouts. Moreover, many killer genes may also perform some central functions in normal mitochondrial or other cellular activities and simply knocking out these genes would cause severe cellular or developmental defects that may mask their predicted apoptotic phenotypes.

Apoptosis is a rapid process. It will therefore be a challenge to study the dynamics of protein-protein and protein-membrane interactions in dying cells in vivo as well as the structures of membrane-bound proteins and captured conformational changes, which are the key to helping us understand the mechanisms of both apoptosis induction and execution. Determination of the nature of oligomeric Bax/Bak pores and the mechanisms underlying Bax translocation and activation are the two "holy grails" that remain to be understood. Answering these questions may also ultimately facilitate our design of more potent and specific chemotherapeutic drugs for cancers and other apoptosis-induced diseases. Finally, our knowledge of apoptosis has been tremendously advanced by forward genetic studies in worms and flies and reverse genetic studies in mice and in biochemical cell-free systems. Challenges will be to develop similar cell-free systems to explore the roles of unknown membrane-bound proteins and to design forward genetic screens in mammalian cell lines or mice to identify novel genes involved in apoptosis, which should fill important gaps in our understanding of cell death.

\section{Acknowledgments}

This work was supported by the Intramural Research Program of the NIH, National Institute of Neurological Disorders and Stroke. We apologize in advance to all the investigators whose research could not be appropriately cited owing to space limitations.

\section{Glossary}

\section{Caspase (cysteine- aspartic acid protease)}

Apoptosome

Inhibitors of apoptosis

(IAP)

B cell lymphoma-2

(Bcl-2) execute apoptosis by cleaving a variety of substrates such as nuclear lamins, ICAD/DEF45, and poly-ADP ribose polymerase

a protein complex responsible for caspase activation. The apoptosome in C. elegans differs significantly from that in mammals

a family of proteins that directly inhibit caspases. They contain a RING domain and Baculoviral IAP repeat (BIR) motifs

a protooncogene responsible for B cell follicular lymphomas due to $\mathrm{t}(14 ; 18)$ chromosomal translocations 


Mitochondria outer
membrane
permeability (MOMP)
PTPC
MEF
IMS
STS
IMM
IBM
PS

responsible for release of Cyt $\mathrm{c}$ and other IMS proteins and is believed to be induced by oligomeric Bax/Bak

permeability transition pore complex

mouse embryonic fibroblast

intermembrane space

staurosporine

inner mitochondria membrane

IAP-binding motif

Phosphatidylserine

\section{LITERATURE CITED}

1. Abdelwahid E, Yokokura T, Krieser RJ, Balasundaram S, Fowle WH, White K. Mitochondrial disruption in Drosophila apoptosis. Dev. Cell. 2007; 12:793-806. [PubMed: 17488629]

2. Anflous K, Armstrong DD, Craigen WJ. Altered mitochondrial sensitivity for ADP and maintenance of creatine-stimulated respiration in oxidative striated muscles from VDAC1-deficient mice. J. Biol. Chem. 2001; 276:1954-1960. [PubMed: 11044447]

3. Antonsson B, Montessuit S, Sanchez B, Martinou JC. Bax is present as a high molecular weight oligomer/complex in the mitochondrial membrane of apoptotic cells. J. Biol. Chem. 2001; 276:11615-11623. [PubMed: 11136736]

4. Arama E, Agapite J, Steller H. Caspase activity and a specific cytochrome c are required for sperm differentiation in Drosophila . Dev. Cell. 2003; 4:687-697. [PubMed: 12737804]

5. Arama E, Bader M, Srivastava M, Bergmann A, Steller H. The two Drosophila cytochrome c proteins can function in both respiration and caspase activation. EMBO J. 2006; 25:232-243. [PubMed: 16362035]

6. Arnoult D, Gaume B, Karbowski M, Sharpe JC, Cecconi F, Youle RJ. Mitochondrial release of AIF and EndoG requires caspase activation downstream of Bax/Bak-mediated permeabilization. EMBO J. 2003; 22:4385-4399. [PubMed: 12941691]

7. Baines CP, Kaiser RA, Purcell NH, Blair NS, Osinska H, et al. Loss of cyclophilin D reveals a critical role for mitochondrial permeability transition in cell death. Nature. 2005; 434:658-662. [PubMed: 15800627]

8. Baines CP, Kaiser RA, Sheiko T, Craigen WJ, Molkentin JD. Voltage-dependent anion channels are dispensable for mitochondrial-dependent cell death. Nat. Cell Biol. 2007; 9:550-555. [PubMed: 17417626]

9. Bao Q, Riedl SJ, Shi Y. Structure of Apaf-1 in the auto-inhibited form: a critical role for ADP. Cell Cycle. 2005; 4:1001-1003. [PubMed: 15970665]

10. Bénit P, Goncalves S, Dassa EP, Briére JJ, Rustin P. The variability of the harlequin mouse phenotype resembles that of human mitochondrial-complex I-deficiency syndromes. PLoS ONE. 2008; 3:e3208. [PubMed: 18791645]

11. Bouillet P, Metcalf D, Huang DC, Tarlinton DM, Kay TW, et al. Proapoptotic Bcl-2 relative Bim required for certain apoptotic responses, leukocyte homeostasis, and to preclude autoimmunity. Science. 1999; 286:1735-1738. [PubMed: 10576740]

12. Boujrad H, Gubkina O, Robert N, Krantic S, Susin SA. AIF-mediated programmed necrosis: a highly regulated way to die. Cell Cycle. 2007; 6:2612-2619. [PubMed: 17912035] 
13. Brown D, Yu BD, Joza N, Benit P, Meneses J, et al. Loss of Aif function causes cell death in the mouse embryo, but the temporal progression of patterning is normal. Proc. Natl. Acad. Sci. USA. 2006; 103:9918-9923. [PubMed: 16788063]

14. Brun S, Rincheval V, Gaumer S, Mignotte B, Guenal I. Reaper and bax initiate two different apoptotic pathways affecting mitochondria and antagonized by bcl-2 in Drosophila . Oncogene. 2002; 21:6458-6470. [PubMed: 12226749]

15. Cecconi F, Alvarez-Bolado G, Meyer BI, Roth KA, Gruss P. Apaf1 (CED-4 homolog) regulates programmed cell death in mammalian development. Cell. 1998; 94:727-737. [PubMed: 9753320]

16. Chai J, Yan N, Huh JR, Wu JW, Li W, et al. Molecular mechanism of Reaper-Grim-Hid-mediated suppression of DIAP1-dependent Dronc ubiquitination. Nat. Struct. Biol. 2003; 10:892-898. [PubMed: 14517550]

17. Cheng EH, Sheiko TV, Fisher JK, Craigen WJ, Korsmeyer SJ. VDAC2 inhibits BAK activation and mitochondrial apoptosis. Science. 2003; 301:513-517. [PubMed: 12881569]

18. Cheung EC, Joza N, Steenaart NA, McClellan KA, Neuspiel M, et al. Dissociating the dual roles of apoptosis-inducing factor in maintaining mitochondrial structure and apoptosis. EMBO J. 2006; 25:4061-4073. [PubMed: 16917506]

19. Chipuk JE, Green DR. How do BCL-2 proteins induce mitochondrial outer membrane permeabilization? Trends Cell Biol. 2008; 18:157-164. [PubMed: 18314333]

20. Claveria C, Martinez-A C, Torres M. A Bax/Bak-independent mitochondrial death pathway triggered by Drosophila Grim GH3 domain in mammalian cells. J. Biol. Chem. 2004; 279:13681375. [PubMed: 14551193]

21. Cory S, Adams JM. The Bcl2 family: regulators of the cellular life-or-death switch. Nat. Rev. Cancer. 2002; 2:647-656. [PubMed: 12209154]

22. David KK, Sasaki M, Yu SW, Dawson TM, Dawson VL. EndoG is dispensable in embryogenesis and apoptosis. Cell Death Differ. 2006; 13:1147-1155. [PubMed: 16239930]

23. Delivani P, Adrain C, Taylor RC, Duriez PJ, Martin SJ. Role for CED-9 and Egl-1 as regulators of mitochondrial fission and fusion dynamics. Mol. Cell. 2006; 21:761-773. [PubMed: 16543146]

24. Deng X, Yin X, Allan R, Lu DD, Maurer CW, et al. Ceramide biogenesis is required for radiationinduced apoptosis in the germ line of C. elegans. Science. 2008; 322:110. [PubMed: 18832646]

25. Deng Y, Ren X, Yang L, Lin Y, Wu X. A JNK-dependent pathway is required for TNFalphainduced apoptosis. Cell. 2003; 115:61-70. [PubMed: 14532003]

26. Dorstyn L, Mills K, Lazebnik Y, Kumar S. The two cytochrome c species, DC3 and DC4, are not required for caspase activation and apoptosis in Drosophila cells. J. Cell Biol. 2004; 167:405-410. [PubMed: 15533997]

27. Du C, Fang M, Li Y, Li L, Wang X. Smac, a mitochondrial protein that promotes cytochrome cdependent caspase activation by eliminating IAP inhibition. Cell. 2000; 102:33-42. [PubMed: 10929711]

28. Duckett CS. IAP proteins: sticking it to Smac. Biochem. J. 2005; 385:e1-e2. [PubMed: 15588250]

29. Eckelman BP, Salvesen GS, Scott FL. Human inhibitor of apoptosis proteins: why XIAP is the black sheep of the family. EMBO Rep. 2006; 7:988-994. [PubMed: 17016456]

30. Ekert PG, Vaux DL. The mitochondrial death squad: hardened killers or innocent bystanders? Curr. Opin. Cell Biol. 2005; 17:626-630. [PubMed: 16219456]

31. Eskes R, Desagher S, Antonsson B, Martinou JC. Bid induces the oligomerization and insertion of Bax into the outer mitochondrial membrane. Mol. Cell. Biol. 2000; 20:929-935. [PubMed: 10629050]

32. Faccio L, Fusco C, Chen A, Martinotti S, Bonventre JV, Zervos AS. Characterization of a novel human serine protease that has extensive homology to bacterial heat shock endoprotease HtrA and is regulated by kidney ischemia. J. Biol. Chem. 2000; 275:2581-2588. [PubMed: 10644717]

33. Frank S, Gaume B, Bergmann-Leitner ES, Leitner WW, Robert EG, et al. The role of dynaminrelated protein 1, a mediator of mitochondrial fission, in apoptosis. Dev. Cell. 2001; 1:515-525. [PubMed: 11703942] 
34. Freel CD, Richardson DA, Thomenius MJ, Gan EC, Horn SR, et al. Mitochondrial localization of Reaper to promote inhibitors of apoptosis protein degradation conferred by GH3 domain-lipid interactions. J. Biol. Chem. 2008; 283:367-379. [PubMed: 17998202]

35. Frezza C, Cipolat S, Martins de Brito O, Micaroni M, Beznoussenko GV, et al. OPA1 controls apoptotic cristae remodeling independently from mitochondrial fusion. Cell. 2006; 126:177-189. [PubMed: 16839885]

36. Fu J, Jin Y, Arend LJ. Smac3, a novel Smac/DIABLO splicing variant, attenuates the stability and apoptosis-inhibiting activity of X-linked inhibitor of apoptosis protein. J. Biol. Chem. 2003; 278:52660-52672. [PubMed: 14523016]

37. Galindo KA, Lu WJ, Park JH, Abrams JM. The Bax/Bak ortholog in Drosophila, Debcl, exerts limited control over programmed cell death. Development. 2009; 136:275-283. [PubMed: 19088092]

38. Galluzzi L, Kroemer G. Mitochondrial apoptosis without VDAC. Nat. Cell Biol. 2007; 9:487-489. [PubMed: 17473857]

39. Geng X, Shi Y, Nakagawa A, Yoshina S, Mitani S, Xue D. Inhibition of CED-3 zymogen activation and apoptosis in Caenorhabditis elegans by caspase homolog CSP-3. Nat. Struct. Mol. Biol. 2008; 15:1094-1101. [PubMed: 18776901]

40. Germain M, Mathai JP, McBride HM, Shore GC. Endoplasmic reticulum BIK initiates DRP1regulated remodelling of mitochondrial cristae during apoptosis. EMBO J. 2005; 24:1546-1556. [PubMed: 15791210]

41. Gonzalvez F, Schug ZT, Houtkooper RH, MacKenzie ED, Brooks DG, et al. Cardiolipin provides an essential activating platform for caspase-8 on mitochondria. J. Cell Biol. 2008; 183:681-696. [PubMed: 19001123]

42. Goyal G, Fell B, Sarin A, Youle RJ, Sriram V. Role of mitochondrial remodeling in programmed cell death in Drosophila melanogaster . Dev. Cell. 2007; 12:807-816. [PubMed: 17488630]

43. Goyal L, McCall K, Agapite J, Hartwieg E, Steller H. Induction of apoptosis by Drosophila reaper, hid and grim through inhibition of IAP function. EMBO J. 2000; 19:589-597. [PubMed: 10675328]

44. Graham BH, Waymire KG, Cottrell B, Trounce IA, MacGregor GR, Wallace DC. A mouse model for mitochondrial myopathy and cardiomyopathy resulting from a deficiency in the heart/muscle isoform of the adenine nucleotide translocator. Nat. Genet. 1997; 16:226-234. [PubMed: 9207786]

45. Griffiths GJ, Dubrez L, Morgan CP, Jones NA, Whitehouse J, et al. Cell damage-induced conformational changes of the proapoptotic protein Bak in vivo precede the onset of apoptosis. J. Cell Biol. 1999; 144:903-914. [PubMed: 10085290]

46. Haining WN, Carboy-Newcomb C, Wei CL, Steller H. The proapoptotic function of Drosophila Hid is conserved in mammalian cells. Proc. Natl. Acad. Sci. USA. 1999; 96:4936-4941. [PubMed: 10220397]

47. Hakem R, Hakem A, Duncan GS, Henderson JT, Woo M, et al. Differential requirement for caspase 9 in apoptotic pathways in vivo. Cell. 1998; 94:339-352. [PubMed: 9708736]

48. Hansen TM, Smith DJ, Nagley P. Smac/DIABLO is not released from mitochondria during apoptotic signaling in cells deficient in cytochrome c. Cell Death Differ. 2006; 13:1181-1190. [PubMed: 16239929]

49. Hao Z, Duncan GS, Chang CC, Elia A, Fang M, et al. Specific ablation of the apoptotic functions of cytochrome $\mathrm{c}$ reveals a differential requirement for cytochrome $\mathrm{c}$ and Apaf-1 in apoptosis. Cell. 2005; 121:579-591. [PubMed: 15907471] Report on a Cyt c knockin mouse model demonstrating the physiological role of Cyt $\mathrm{c}$ in apoptosis

50. Hasenjäger A, Gillissen B, Müller A, Normand G, Hemmati PG, et al. Smac induces cytochrome c release and apoptosis independently from $\mathrm{Bax} / \mathrm{Bcl}-\mathrm{x}(\mathrm{L})$ in a strictly caspase-3-dependent manner in human carcinoma cells. Oncogene. 2004; 23:4523-4535. [PubMed: 15064710]

51. Hegde R, Srinivasula SM, Zhang Z, Wassell R, Mukattash R, et al. Identification of Omi/HtrA2 as a mitochondrial apoptotic serine protease that disrupts inhibitor of apoptosis protein-caspase interaction. J. Biol. Chem. 2002; 277:432-438. [PubMed: 11606597] 
52. Hockenbery D, Nunez G, Milliman C, Schreiber R, Korsmeyer SJ. Bcl-2 is an inner mitochondrial membrane protein that blocks programmed cell death. Nature. 1990; 348:334-336. [PubMed: 2250705]

53. Hockenbery DM, Oltvai ZN, Yin XM, Milliman CL, Korsmeyer SJ. Bcl-2 functions in an antioxidant pathway to prevent apoptosis. Cell. 1993; 75:241-251. [PubMed: 7503812]

54. Hsu YT, Wolter KG, Youle RJ. Cytosol-to-membrane redistribution of Bax and Bcl-X(L) during apoptosis. Proc. Natl. Acad. Sci. USA. 1997; 94:3668-3672. [PubMed: 9108035] First report indicating Bax translocates to mitochondria during apoptosis

55. Hu Y, Ding L, Spencer DM, Nunez G. WD-40 repeat region regulates Apaf-1 self-association and procaspase-9 activation. J. Biol. Chem. 1998; 273:33489-33494. [PubMed: 9837928]

56. Huh JR, Vernooy SY, Yu H, Yan N, Shi Y, et al. Multiple apoptotic caspase cascades are required in nonapoptotic roles for Drosophila spermatid individualization. PLoS Biol. 2004; 2:E15. [PubMed: 14737191]

57. Igaki T, Kanuka H, Inohara N, Sawamoto K, Núñez G, et al. Drob-1, a Drosophila member of the Bcl-2/CED-9 family that promotes cell death. Proc. Natl. Acad. Sci. USA. 2000; 97:662-667. [PubMed: 10639136]

58. Irvine RA, Adachi N, Shibata DK, Cassell GD, Yu K, et al. Generation and characterization of endonuclease G null mice. Mol. Cell. Biol. 2005; 25:294-302. [PubMed: 15601850]

59. Jacobson MD, Burne JF, Raff MC. Programmed cell death and Bcl-2 protection in the absence of a nucleus. EMBO J. 1994; 13:1899-1910. [PubMed: 8168488]

60. Jones JM, Datta P, Srinivasula SM, Ji W, Gupta S, et al. Loss of Omi mitochondrial protease activity causes the neuromuscular disorder of mnd 2 mutant mice. Nature. 2003; 425:721-727. [PubMed: 14534547]

61. Joza N, Oudit GY, Brown D, Bénit P, Kassiri Z, et al. Muscle-specific loss of apoptosis-inducing factor leads to mitochondrial dysfunction, skeletal muscle atrophy, and dilated cardiomyopathy. Mol. Cell. Biol. 2005; 25:10261-10272. [PubMed: 16287843]

62. Joza N, Susin SA, Daugas E, Stanford WL, Cho SK, et al. Essential role of the mitochondrial apoptosis-inducing factor in programmed cell death. Nature. 2001; 410:549-554. [PubMed: 11279485]

63. Karbowski M, Norris KL, Cleland MM, Jeong SY, Youle RJ. Role of Bax and Bak in mitochondrial morphogenesis. Nature. 2006; 443:658-662. [PubMed: 17035996]

64. Kerr J, Wyllie A, Currie A. Apoptosis: a basic biological phenomenon with wide-ranging implications in tissue kinetics. Br. J. Cancer. 1972; 26:239-257. [PubMed: 4561027] The seminal paper for the term apoptosis.

65. Kim H, Rafiuddin-Shah M, Tu HC, Jeffers JR, Zambetti GP, et al. Hierarchical regulation of mitochondrion-dependent apoptosis by BCL-2 subfamilies. Nat. Cell Biol. 2006; 8:1348-1358. [PubMed: 17115033]

66. Kim HE, Du F, Fang M, Wang X. Formation of apoptosome is initiated by cytochrome c-induced dATP hydrolysis and subsequent nucleotide exchange on Apaf-1. Proc. Natl. Acad. Sci. USA. 2005; 102:17545-17550. [PubMed: 16251271]

67. Kinnally KW, Antonsson B. A tale of two mitochondrial channels, MAC and PTP, in apoptosis. Apoptosis. 2007; 12:857-868. [PubMed: 17294079]

68. Klein JA, Longo-Guess CM, Rossmann MP, Seburn KL, Hurd RE, et al. The harlequin mouse mutation downregulates apoptosis-inducing factor. Nature. 2002; 419:367-374. [PubMed: 12353028]

69. Kluck RM, Bossy-Wetzel E, Green DR, Newmeyer DD. The release of cytochrome c from mitochondria: a primary site for Bcl-2 regulation of apoptosis. Science. 1997; 275:1132-1136. [PubMed: 9027315] Back-to-back papers demonstrating that the primary antiapoptotic function of Bcl-2 is to block Cyt c release

70. Kohli M, Yu J, Seaman C, Bardelli A, Kinzler KW, et al. SMAC/Diablo-dependent apoptosis induced by nonsteroidal antiinflammatory drugs (NSAIDs) in colon cancer cells. Proc. Natl. Acad. Sci. USA. 2004; 101:16897-16902. [PubMed: 15557007] 
71. Kokoszka JE, Waymire KG, Levy SE, Sligh JE, Cai J, et al. The ADP/ATP translocator is not essential for the mitochondrial permeability transition pore. Nature. 2004; 427:461-465. [PubMed: 14749836]

72. Krauskopf A, Eriksson O, Craigen WJ, Forte MA, Bernardi P. Properties of the permeability transition in VDAC1(-/-) mitochondria. Biochim. Biophys. Acta. 2006; 1757:590-595. [PubMed: 16626625]

73. Kroemer G, Galluzzi L, Brenner C. Mitochondrial membrane permeabilization in cell death. Physiol. Rev. 2007; 87:99-163. [PubMed: 17237344]

74. Kroemer G, Petit P, Zamzami N, Vayssie`re JL, Mignotte B. The biochemistry of programmed cell death. FASEB J. 1995; 9:1277-1287. [PubMed: 7557017]

75. Kuida K, Haydar TF, Kuan CY, Gu Y, Taya C, et al. Reduced apoptosis and cytochrome cmediated caspase activation in mice lacking caspase 9. Cell. 1998; 94:325-337. [PubMed: 9708735]

76. Kuwana T, Mackey MR, Perkins G, Ellisman MH, Latterich M, et al. Bid, Bax, and lipids cooperate to form supramolecular openings in the outer mitochondrial membrane. Cell. 2002; 111:331-342. [PubMed: 12419244]

77. Lakhani S, Masud A, Kuida K, Porter GA Jr, Booth C, et al. Caspases 3 and 7: key mediators of mitochondrial events of apoptosis. Science. 2006; 311:847-851. [PubMed: 16469926]

78. Leber B, Lin J, Andrews DW. Embedded together: the life and death consequences of interaction of the Bcl-2 family with membranes. Apoptosis. 2007; 12:897-911. [PubMed: 17453159]

79. Lee YJ, Jeong SY, Karbowski M, Smith CL, Youle RJ. Roles of the mammalian mitochondrial fission and fusion mediators Fis1, Drp1, and Opa1 in apoptosis. Mol. Biol. Cell. 2004; 15:50015011. [PubMed: 15356267]

80. Lettre G, Hengartner MO. Developmental apoptosis in C. elegans: a complex CEDnario. Nat. Rev. Mol. Cell. Biol. 2006; 7:97-108. [PubMed: 16493416]

81. Li H, Zhu H, Xu CJ, Yuan J. Cleavage of BID by caspase 8 mediates the mitochondrial damage in the Fas pathway of apoptosis. Cell. 1998; 94:491-501. [PubMed: 9727492] Back-to-back papers discovering the crosstalk between extrinsic pathway and intrinsic pathway

82. Li K, Li Y, Shelton JM, Richardson JA, Spencer E, et al. Cytochrome c deficiency causes embryonic lethality and attenuates stress-induced apoptosis. Cell. 2000; 101:389-399. [PubMed: 10830166]

83. Li LY, Luo X, Wang X. Endonuclease G is an apoptotic DNase when released from mitochondria. Nature. 2001; 412:95-99. [PubMed: 11452314]

84. Li P, Nijhawan D, Budihardjo I, Srinivasula SM, Ahmad M, et al. Cytochrome c and dATPdependent formation of Apaf-1/caspase-9 complex initiates an apoptotic protease cascade. Cell. 1997; 91:479-489. [PubMed: 9390557]

85. Lindsten T, Ross AJ, King A, Zong WX, Rathmell JC, et al. The combined functions of proapoptotic Bcl-2 family members bak and bax are essential for normal development of multiple tissues. Mol. Cell. 2000; 6:1389-1399. [PubMed: 11163212]

86. Liu X, Kim CN, Yang J, Jemmerson R, Wang X. Induction of apoptotic program in cell-free extracts: requirement for dATP and cytochrome c. Cell. 1996; 86:147-157. [PubMed: 8689682] First paper to demonstrate the role of Cyt $\mathrm{c}$ in caspase activation

87. Lovell JF, Billen LP, Bindner S, Shamas-Din A, Fradin C, et al. Membrane binding by tBid initiates an ordered series of events culminating in membrane permeabilization by Bax. Cell. 2008; 135:1074-1084. [PubMed: 19062087]

88. Low RL. Mitochondrial endonuclease $\mathrm{G}$ function in apoptosis and mtDNA metabolism: a historical perspective. Mitochondrion. 2003; 2:225-236. [PubMed: 16120323]

89. Luo X, Budihardjo I, Zou H, Slaughter C, Wang X. Bid, a Bcl2 interacting protein, mediates cytochrome $\mathrm{c}$ release from mitochondria in response to activation of cell surface death receptors. Cell. 1998; 94:481-490. [PubMed: 9727491] Back-to-back papers discovering the crosstalk between extrinsic pathway and intrinsic pathway

90. Lutter M, Fang M, Luo X, Nishijima M, Xie X, Wang X. Cardiolipin provides specificity for targeting of tBid to mitochondria. Nat. Cell Biol. 2000; 2:754-761. [PubMed: 11025668] 
91. Marsden VS, O’Connor L, O’Reilly LA, Silke J, Metcalf D, et al. Apoptosis initiated by Bcl-2regulated caspase activation independently of the cytochrome c/Apaf-1/caspase- 9 apoptosome. Nature. 2002; 419:634-637. [PubMed: 12374983]

92. Martins LM, Iaccarino I, Tenev T, Gschmeissner S, Totty NF, et al. The serine protease Omi/ HtrA2 regulates apoptosis by binding XIAP through a reaper-like motif. J. Biol. Chem. 2002; 277:439-444. [PubMed: 11602612]

93. Martins LM, Morrison A, Klupsch K, Fedele V, Moisoi N, et al. Neuroprotective role of the Reaper-related serine protease HtrA2/Omi revealed by targeted deletion in mice. Mol. Cell. Biol. 2004; 24:9848-9862. [PubMed: 15509788]

94. Mendes CS, Arama E, Brown S, Scherr H, Srivastava M, et al. Cytochrome c-d regulates developmental apoptosis in the Drosophila retina. EMBO Rep. 2006; 7:933-939. [PubMed: 16906130]

95. Morizane Y, Honda R, Fukami K, Yasuda H. X-linked inhibitor of apoptosis functions as ubiquitin ligase toward mature caspase-9 and cytosolic Smac/DIABLO. J. Biochem. 2005; 137:125-132. [PubMed: 15749826]

96. Muchmore SW, Sattler M, Liang H, Meadows RP, Harlan JE, et al. X-ray and NMR structure of human Bcl-xL, an inhibitor of programmed cell death. Nature. 1996; 381:335-341. [PubMed: 8692274]

97. Muro I, Monser K, Clem RJ. Mechanism of Dronc activation in Drosophila cells. J. Cell Sci. 2004; 117:5035-5041. [PubMed: 15383617]

98. Nakagawa T, Shimizu S, Watanabe T, Yamaguchi O, Otsu K, et al. Cyclophilin D-dependent mitochondrial permeability transition regulates some necrotic but not apoptotic cell death. Nature. 2005; 434:652-658. [PubMed: 15800626]

99. Newmeyer DD, Farschon DM, Reed JC. Cell-free apoptosis in Xenopus egg extracts: inhibition by Bcl-2 and requirement for an organelle fraction enriched in mitochondria. Cell. 1994; 79:353-364. [PubMed: 7954801] First report on the requirement of mitochondria for apoptosis using cell-free system

100. Okada H, Suh W, Jin J, Woo M, Du C, et al. Generation and characterization of Smac/DIABLOdeficient mice. Mol. Cell. Biol. 2002; 22:3509-3517. [PubMed: 11971981]

101. Olson MR, Holley CL, Gan EC, Colon-Ramos DA, Kaplan B, Kornbluth S. A GH3-like domain in reaper is required for mitochondrial localization and induction of IAP degradation. J. Biol. Chem. 2003; 278:44758-44768. [PubMed: 12917412]

102. Ow YL, Green DR, Hao Z, Mak TW. Cytochrome c: functions beyond respiration. Nat. Rev. Mol. Cell Biol. 2008; 9:532-542. [PubMed: 18568041]

103. Pardo OE, Lesay A, Arcaro A, Lopes R, Ng BL, et al. Fibroblast growth factor 2-mediated translational control of IAPs blocks mitochondrial release of Smac/DIABLO and apoptosis in small cell lung cancer cells. Mol. Cell. Biol. 2003; 23:7600-7610. [PubMed: 14560006]

104. Parone PA, James DI, Da Cruz S, Mattenberger Y, Donze O, et al. Inhibiting the mitochondrial fission machinery does not prevent Bax/Bak-dependent apoptosis. Mol. Cell. Biol. 2006;

26:7397-7408. [PubMed: 17015472]

105. Parrish J, Li L, Klotz K, Ledwich D, Wang X, Xue D. Mitochondrial endonuclease G is important for apoptosis in C. elegans . Nature. 2001; 412:90-94. [PubMed: 11452313]

106. Pospisilik JA, Knauf C, Joza N, Benit P, Orthofer M, et al. Targeted deletion of AIF decreases mitochondrial oxidative phosphorylation and protects from obesity and diabetes. Cell. 2007; 131:476-491. [PubMed: 17981116]

107. Quinn L, Coombe M, Mills K, Daish T, Colussi P, et al. Buffy, a Drosophila Bcl-2 protein, has antiapoptotic and cell cycle inhibitory functions. EMBO J. 2003; 22:3568-3579. [PubMed: 12853472]

108. Rehm M, Düssmann H, Prehn JH. Real-time single cell analysis of Smac/DIABLO release during apoptosis. J. Cell Biol. 2003; 162:1031-1043. [PubMed: 12975347]

109. Roberts DL, Merrison W, MacFarlane M, Cohen GM. The inhibitor of apoptosis protein-binding domain of Smac is not essential for its proapoptotic activity. J. Cell Biol. 2001; 153:221-228. [PubMed: 11285287] 
110. Rodriguez A, Chen P, Oliver H, Abrams JM. Unrestrained caspase-dependent cell death caused by loss of Diap1 function requires the Drosophila Apaf-1 homolog, Dark. EMBO J. 2002; 21:2189-2197. [PubMed: 11980716]

111. Rodriguez A, Oliver H, Zou H, Chen P, Wang X, Abrams JM. Dark is a Drosophila homologue of Apaf-1/CED-4 and functions in an evolutionarily conserved death pathway. Nat. Cell Biol. 1999; 1:272-279. [PubMed: 10559939]

112. Salvesen GS, Dixit VM. Caspases: intracellular signaling by proteolysis. Cell. 1997; 91:443-446. [PubMed: 9390553]

113. Schäfer P, Scholz SR, Gimadutdinow O, Cymerman IA, Bujnicki JM, et al. Structural and functional characterization of mitochondrial EndoG, a sugar nonspecific nuclease which plays an important role during apoptosis. J. Mol. Biol. 2004; 338:217-228. [PubMed: 15066427]

114. Scorrano L, Ashiya M, Buttle K, Weiler S, Oakes SA, et al. A distinct pathway remodels mitochondrial cristae and mobilizes cytochrome c during apoptosis. Dev. Cell. 2002; 2:55-67. [PubMed: 11782314]

115. Sevrioukov EA, Burr J, Huang EW, Assi HH, Monserrate JP, et al. Drosophila Bcl-2 proteins participate in stress-induced apoptosis, but are not required for normal development. Genesis. 2007; 45:184-193. [PubMed: 17417787]

116. Shi Y. Apoptosome assembly. Methods Enzymol. 2008; 442:141-156. [PubMed: 18662568]

117. Silke J, Ekert PG, Day CL, Hawkins CJ, Baca M, et al. Direct inhibition of caspase 3 is dispensable for the antiapoptotic activity of XIAP. EMBO J. 2001; 20:3114-3123. [PubMed: 11406588]

118. Deleted in Proof

119. Srinivasula SM, Datta P, Fan XJ, Fernandes-Alnemri T, Huang Z, Alnemri ES. Molecular determinants of the caspase-promoting activity of Smac/DIABLO and its role in the death receptor pathway. J. Biol. Chem. 2000; 275:36152-36157. [PubMed: 10950947]

120. Srinivasula SM, Hegde R, Saleh A, Datta P, Shiozaki E, et al. A conserved XIAP-interaction motif in caspase-9 and Smac/DIABLO regulates caspase activity and apoptosis. Nature. 2001; 410:112-116. [PubMed: 11242052]

121. Suen DF, Norris KL, Youle RJ. Mitochondrial dynamics and apoptosis. Genes Dev. 2008; 22:1577-1590. [PubMed: 18559474]

122. Sun MG, Williams J, Munoz-Pinedo C, Perkins GA, Brown JM, et al. Correlated threedimensional light and electron microscopy reveals transformation of mitochondria during apoptosis. Nat. Cell Biol. 2007; 9:1057-1065. [PubMed: 17721514]

123. Susin SA, Lorenzo HK, Zamzami N, Marzo I, Snow BE, et al. Molecular characterization of mitochondrial apoptosis-inducing factor. Nature. 1999; 397:441-446. [PubMed: 9989411]

124. Susin SA, Zamzami N, Castedo M, Hirsch T, Marchetti P, et al. Bcl-2 inhibits the mitochondrial release of an apoptogenic protease. J. Exp. Med. 1996; 184:1331-1341. [PubMed: 8879205]

125. Suzuki Y, Imai Y, Nakayama H, Takahashi K, Takio K, Takahashi R. A serine protease, HtrA2, is released from the mitochondria and interacts with XIAP, inducing cell death. Mol. Cell. 2001; 8:613-621. [PubMed: 11583623]

126. Tan FJ, Fire AZ, Hill RB. Regulation of apoptosis by C. elegans CED-9 in the absence of the Cterminal transmembrane domain. Cell Death Differ. 2007; 14:1925-1935. [PubMed: 17703231]

127. Tenev T, Zachariou A, Wilson R, Paul A, Meier P. Jafrac 2 is an IAP antagonist that promotes cell death by liberating Dronc from DIAP1. EMBO J. 2002; 21:5118-5129. [PubMed: 12356728]

128. Urbano A, Lakshmanan U, Choo PH, Kwan JC, Ng PY, et al. AIF suppresses chemical stressinduced apoptosis and maintains the transformed state of tumor cells. EMBO J. 2005; 24:28152826. [PubMed: 16001080]

129. Deleted in Proof

130. van Loo G, van Gurp M, Depuydt B, Srinivasula SM, Rodriguez I, et al. The serine protease Omi/ $\mathrm{HtrA} 2$ is released from mitochondria during apoptosis. Omi interacts with caspase-inhibitor XIAP and induces enhanced caspase activity. Cell Death Differ. 2002; 9:20-26. [PubMed: 11803371]

131. Vande Walle L, Lamkanfi M, Vandenabeele P. The mitochondrial serine protease HtrA2/Omi: an overview. Cell Death Differ. 2008; 15:453-460. [PubMed: 18174901] 
132. Verhagen AM, Ekert PG, Pakusch M, Silke J, Connolly LM, et al. Identification of DIABLO, a mammalian protein that promotes apoptosis by binding to and antagonizing IAP proteins. Cell. 2000; 102:43-53. [PubMed: 10929712]

133. Wang X, Wang J, Gengyo-Ando K, Gu L, Sun CL, et al. C. elegans mitochondrial factor WAH-1 promotes phosphatidylserine externalization in apoptotic cells through phospholipid scramblase SCRM-1. Nat. Cell Biol. 2007; 9:541-549. [PubMed: 17401362]

134. Wang X, Yang C, Chai J, Shi Y, Xue D. Mechanisms of AIF-mediated apoptotic DNA degradation in Caenorhabditis elegans . Science. 2002; 298:1587-1592. [PubMed: 12446902]

135. Wei MC, Zong WX, Cheng EH, Lindsten T, Panoutsakopoulou V, et al. Proapoptotic BAX and BAK: a requisite gateway to mitochondrial dysfunction and death. Science. 2001; 292:727-730. [PubMed: 11326099]

136. White K, Grether M, Abrams J, Young L, Steller H. Genetic control of programmed cell death in Drosophila . Science. 1994; 264:1-7. First genetic screen to identify genes essential for fly apoptosis

137. Widlak P, Li LY, Wang X, Garrard WT. Action of recombinant human apoptotic endonuclease G on naked DNA and chromatin substrates: cooperation with exonuclease and DNase I. J. Biol. Chem. 2001; 276:48404-48409. [PubMed: 11606588]

138. Willis SN, Fletcher JI, Kaufmann T, van Delft MF, Chen L, et al. Apoptosis initiated when BH3 ligands engage multiple Bcl-2 homologs, not Bax or Bak. Science. 2007; 315:856-859. [PubMed: 17289999]

139. Wilson R, Goyal L, Ditzel M, Zachariou A, Baker DA, et al. The DIAP1 RING finger mediates ubiquitination of Dronc and is indispensable for regulating apoptosis. Nat. Cell Biol. 2002; 4:445-450. [PubMed: 12021771]

140. Wolter KG, Hsu YT, Smith CL, Nechushtan A, Xi XG, Youle RJ. Movement of Bax from the cytosol to mitochondria during apoptosis. J. Cell Biol. 1997; 139:1281-1292. [PubMed: 9382873]

141. Wu S, Sampson MJ, Decker WK, Craigen WJ. Each mammalian mitochondrial outer membrane porin protein is dispensable: effects on cellular respiration. Biochim. Biophys. Acta. 1999; 1452:68-78. [PubMed: 10525161]

142. Yamaguchi R, Lartigue L, Perkins G, Scott RT, Dixit A, et al. Opa1-mediated cristae opening is $\mathrm{Bax} / \mathrm{Bak}$ and $\mathrm{BH} 3$ dependent, required for apoptosis, and independent of Bak oligomerization. Mol. Cell. 2008; 31:557-569. [PubMed: 18691924]

143. Yamaguchi R, Perkins G. Dynamics of mitochondrial structure during apoptosis and the enigma of Opa1. Biochim. Biophys. Acta. 2009; 1787:963-972. [PubMed: 19245786]

144. Yan N, Chai J, Lee ES, Gu L, Liu Q, et al. Structure of the CED-4-CED-9 complex provides insights into programmed cell death in Caenorhabditis elegans . Nature. 2005; 437:831-837. [PubMed: 16208361]

145. Yan N, Xu Y, Shi Y. 2:1 Stoichiometry of the CED-4-CED-9 complex and the tetrameric CED-4: insights into the regulation of CED-3 activation. Cell Cycle. 2006; 5:31-34. [PubMed: 16294007]

146. Yang J, Liu X, Bhalla K, Kim CN, Ibrado AM, et al. Prevention of apoptosis by Bcl-2: release of cytochrome c from mitochondria blocked. Science. 1997; 275:1129-1132. [PubMed: 9027314] Back-to-back papers demonstrating that the primary antiapoptotic function of Bcl-2 is to block Cyt c release

147. Yang QH, Church-Hajduk R, Ren J, Newton ML, Du C. Omi/HtrA2 catalytic cleavage of inhibitor of apoptosis (IAP) irreversibly inactivates IAPs and facilitates caspase activity in apoptosis. Genes Dev. 2003; 17:1487-1496. [PubMed: 12815069]

148. Ye H, Cande C, Stephanou NC, Jiang S, Gurbuxani S, et al. DNA binding is required for the apoptogenic action of apoptosis inducing factor. Nat. Struct. Biol. 2002; 9:680-684. [PubMed: 12198487]

149. Yoo SJ, Huh JR, Muro I, Yu H, Wang L, et al. Hid, Rpr and Grim negatively regulate DIAP1 levels through distinct mechanisms. Nat. Cell Biol. 2002; 4:416-424. [PubMed: 12021767]

150. Yoshida H, Kong YY, Yoshida R, Elia AJ, Hakem A, et al. Apaf1 is required for mitochondrial pathways of apoptosis and brain development. Cell. 1998; 94:739-750. [PubMed: 9753321] 
151. Youle RJ, Karbowski M. Mitochondrial fission in apoptosis. Nat. Rev. Mol. Cell Biol. 2005; 6:657-663. [PubMed: 16025099]

152. Youle RJ, Strasser A. The BCL-2 protein family: opposing activities that mediate cell death. Nat. Rev. Mol. Cell Biol. 2008; 9:47-59. [PubMed: 18097445]

153. Yu X, Wang L, Acehan D, Wang X, Akey CW. Three-dimensional structure of a double apoptosome formed by the Drosophila Apaf-1 related killer. J. Mol. Biol. 2006; 355:577-589. [PubMed: 16310803]

154. Yuan J, Shaham S, Ledoux S, Ellis HM, Horvitz HR. The C. elegans cell death gene ced-3 encodes a protein similar to mammalian interleukin-1 beta-converting enzyme. Cell. 1993; 75:641-652. [PubMed: 8242740]

155. Yuste VJ, Moubarak RS, Delettre C, Bras M, Sancho P, et al. Cysteine protease inhibition prevents mitochondrial apoptosis-inducing factor (AIF) release. Cell Death Differ. 2005; 12:1445-1448. [PubMed: 15933737]

156. Zamzami N, Susin SA, Marchetti P, Hirsch T, Gómez-Monterrey I, et al. Mitochondrial control of nuclear apoptosis. J. Exp. Med. 1996; 183:1533-1544. [PubMed: 8666911]

157. Zhang H, Huang Q, Ke N, Matsuyama S, Hammock B, et al. Drosophila proapoptotic Bcl-2/Bax homologue reveals evolutionary conservation of cell death mechanisms. J. Biol. Chem. 2000; 275:27303-27306. [PubMed: 10811653]

158. Zhang J, Dong M, Li L, Fan Y, Pathre P, et al. Endonuclease G is required for early embryogenesis and normal apoptosis in mice. Proc. Natl. Acad. Sci. USA. 2003; 100:1578215787. [PubMed: 14663139]

159. Zhou LL, Zhou LY, Luo KQ, Chang DC. Smac/DIABLO and cytochrome c are released from mitochondria through a similar mechanism during UV-induced apoptosis. Apoptosis. 2005; 10:289-299. [PubMed: 15843890]

160. Zong WX, Lindsten T, Ross AJ, MacGregor GR, Thompson CB. BH3-only proteins that bind prosurvival Bcl-2 family members fail to induce apoptosis in the absence of Bax and Bak. Genes Dev. 2001; 15:1481-1486. [PubMed: 11410528] Establishes that BH3-only proteins and Bcl-2 proteins act through Bax /Bak dependent pathway 


\section{EXTRINSIC APOPTOSIS PATHWAY}

The extrinsic pathway, also known as the death-receptor pathway, is activated from outside the cell by ligation of transmembrane death receptors such as Fas, TNF, TRAIL, and DR3-6 receptors with their corresponding ligands. Upon activation, each receptor can form a death-inducing signaling complex (DISC) by recruiting the adaptor Fasassociated death domain (FADD) and apical procaspase-8 and -10 . As a consequence, caspase- 8 and -10 are activated, which directly cleave and activate effector caspase-3/7. 


\section{SUMMARY POINTS}

1. Mitochondria actively participate in vertebrate cell death through different mechanisms by releasing various cytotoxic proteins. For instance, Cyt c is required for caspase activation; Smac/DIABLO and Omi/HtrA2 can block the inhibitory effects of IAPs.

2. The release of Cyt $\mathrm{c}$ and other IMS proteins is regulated by Bcl-2 family proteins through interplay between proapoptotic and antiapoptotic proteins and protein-lipid interactions, which converge to Bax/Bak activation. Oligomeric Bax/Bak induces mitochondrial outer membrane permeability (MOMP).

However, the molecular mechanisms underlying Bax/Bak activation and MOMP remain unclear.

3. In C. elegans, the Bcl-2 homolog protein, Ced-9, is localized on mitochondria and binds directly to Ced-4, an Apaf-1 homolog, to inhibit Ced-3 activation. However, in vertebrates, Bcl-2 does not interact with Apaf-1, and Apaf-1 exists in an auto-inhibited form. Although worms also have endoG and AIF homologs, deletion of them only results in weak cell death phenotypes. Hence, the role of mitochondria in C. elegans apoptosis is not clear.

4. In flies, IAP antagonists Reaper, Hid, and Grim play much greater roles in apoptosis than mammalian counterparts Smac and Omi. In addition, removal of DIAP1 causes spontaneous cell death, whereas in mammals, XIAP KO mice display no clear apoptotic phenotypes, highlighting the difference between the two species. Whereas Cyt $\mathrm{c}$ release remains a controversial issue in fly apoptosis, it is even less clear how assembly of Dark, an Apaf-1 homolog, is regulated in vivo. 


\section{FUTURE ISSUES}

1. How did mitochondria and Bcl-2 family proteins evolve to regulate apoptosis and how have the apoptosis pathways diverged in C. elegans, Drosophila, and vertebrates? Are there missing links that prevent us from reaching a unifying model for the role of mitochondria and $\mathrm{Bcl}-2$ family proteins in animals?

2. What is the mechanism underlying Bax/Bak activation? Are BH3-only proteins the activators? How do antiapoptotic Bcl-2 proteins inhibit Bax/Bak activation by binding Bax/Bak, BH3-only proteins or both?

3. What is the nature of oligomeric Bax/Bak induced pores? How does the structure of Bax in the membrane compare with that of Bax in solution?

4. Is there a Cyt c-independent apoptosis pathway in mammals and how important might it be?

5. As genetic data so far do not correlate with biochemical data regarding their roles in apoptosis, how important are other proteins released from mitochondria? Are they released in the same way as Cyt $\mathrm{c}$ ? 


\section{Caenorhabditis elegans}

Healthy
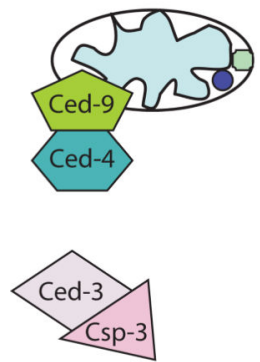

$\underset{\text { Survival }}{\downarrow}$
Apoptotic
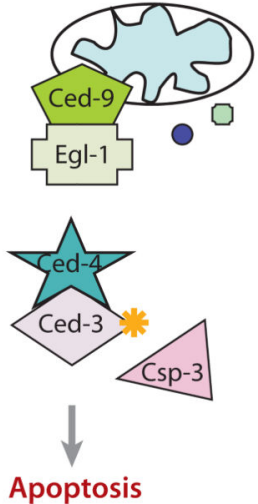

\section{Drosophila}

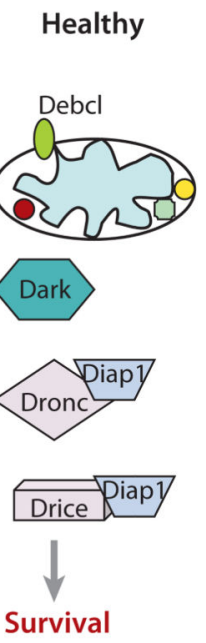

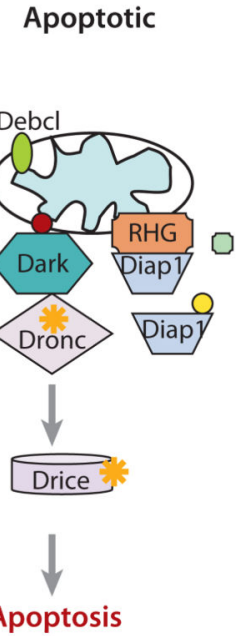

\section{Vertebrate}

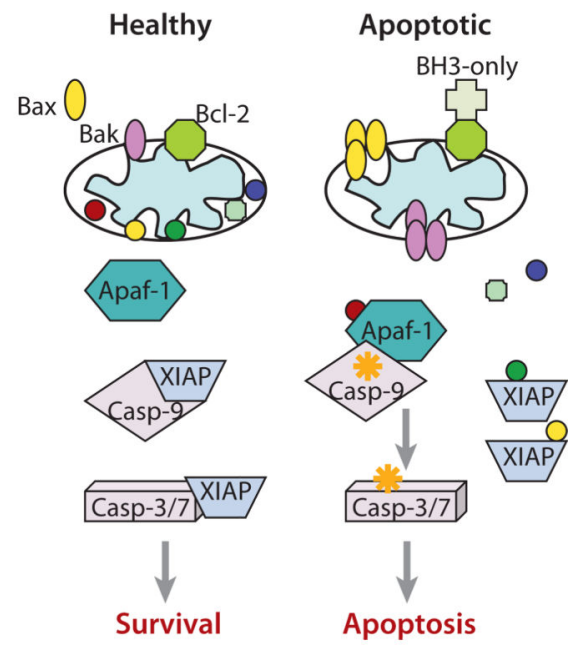

\begin{tabular}{lll}
\hline Csp-6/endoG & $O$ Omi/HtrA2/dOmi & Smac/DIABLO \\
Wah-1/AIF & $\bigcirc$ Cyt c & *activated form
\end{tabular}

Figure 1.

The role of mitochondria in apoptosis in three model systems. In Caenorhabditis elegans, Ced- 4 is constantly bound by Ced- 9 on the mitochondrial outer membrane in healthy cells. Ced-3 is bound by Csp-3, a caspase homolog without the large subunit to prevent inadvertent Ced-3 auto-activation. Egl-1, a BH3-only protein, is transcriptionally regulated during development or in response to apoptotic stimuli. Egl-1 binds to Ced-9 to displace Ced-4, which is now free to form a tetramer and is capable of activating Ced-3 to trigger cell death. Csp-3 is displaced by Ced-4 and its inhibitory effect on Ced-3 is removed.

Meanwhile, Csp-6 and Wah-1 are possibly released from mitochondria and trigger caspaseindependent molecular events to facilitate the dismantling of the cell content, such as nuclear DNA fragmentation and phosphatidylserine (PS) exposure for signaling cell engulfment. In Drosophila, the caspases (Dronc and Drice) are ubiquitinated by Diap-1 for proteosomal degradation in healthy cells. Upon developmental or apoptotic signals, Reaper, Hid, and Grim (RHG) genes are transcriptionally induced, and the proteins translocate to mitochondria to recruit Diap-1 for interaction. The membrane association of RHG proteins has been shown to be required for RHG-mediated Diap-1 auto-ubiquitination and degradation. Meanwhile, Cyt c might be released or remain on the surface of the mitochondrial outer membrane after some conformational changes, which now can bind to Dark and trigger apoptosome formation. dOmi might be released or remain on the mitochondria and interact with Diap-1 to further free the caspases from Diap-1 inhibition. DmAIF is released to trigger caspase-independent events. Sickle and Jafrac2 behave like RHG proteins, but Jafrac is localized to the ER (127). Localization of Sickle is not clear. In healthy cells of vertebrates, Apaf- 1 is in an auto-inhibited form and any basally processed caspase- 9 and caspase- $3 / 7$ are bound by XIAP and hence, remain inactive. Upon apoptotic signaling, BH3-only proteins are either upregulated transcriptionally or activated through post-translational modification. They then bind to antiapoptotic Bcl-2 proteins to remove their inhibitory effect or activate Bax/Bak directly. Protein-lipid interaction might also be 
involved in Bax/Bak activation, which leads to their oligomerization and triggers release of Cyt c, Smac/DIABLO, endoG, AIF, and Omi/HtrA2. Cytosolic Cyt c then binds to Apaf-1 to induce apoptosome formation, leading to caspase- 9 and caspase-3/7 activation. Smac/ DIABLO and Omi/HtrA2 bind to XIAP to remove its inhibitory effect. Ortholog proteins in different species are labeled in the same color. 

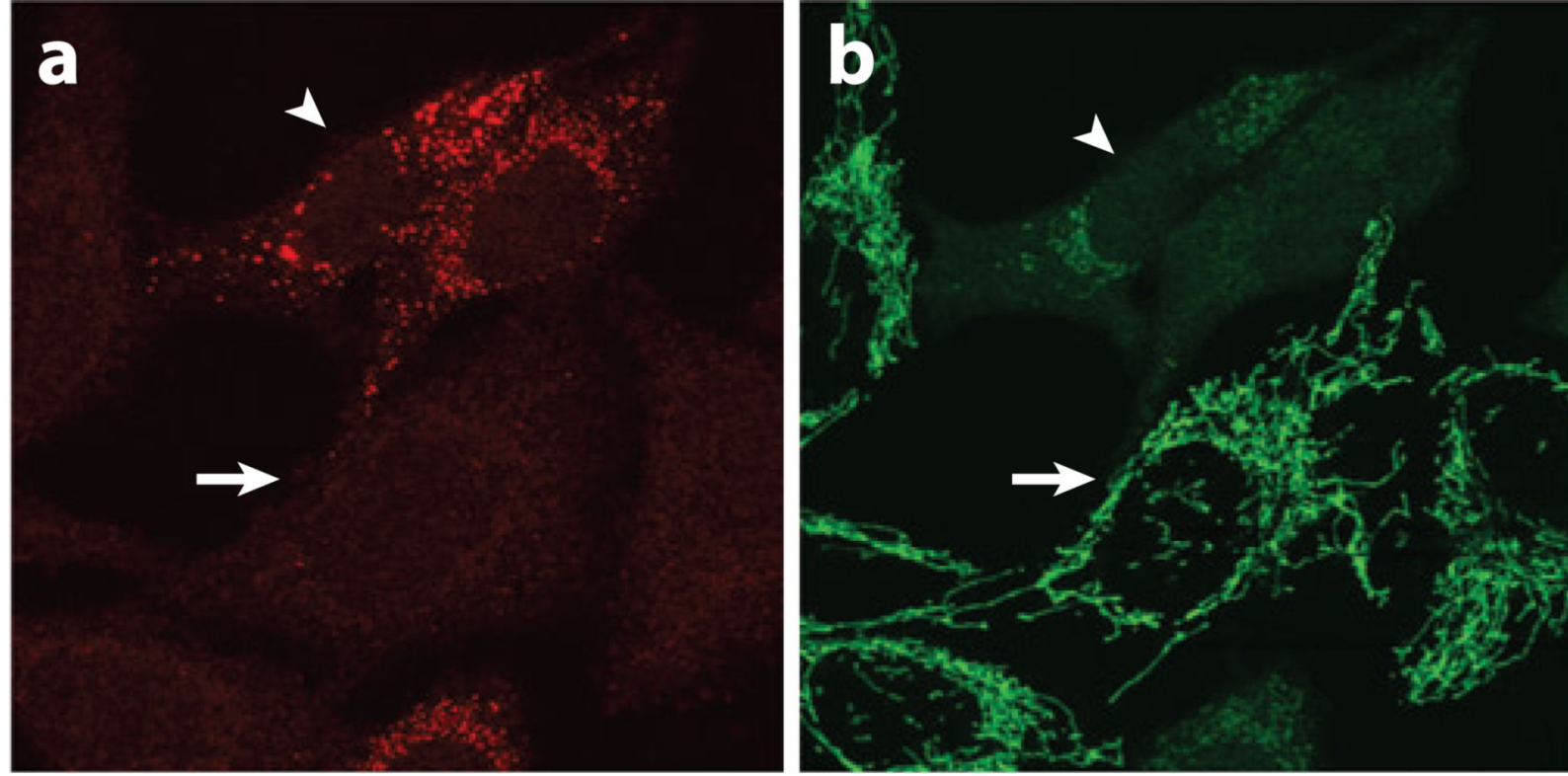

Bax

Figure 2.

Bax translocation and Cyt c release during apoptosis. In healthy Hela cells, Bax (red) is mainly in the cytosol whereas Cyt c (green) resides inside the mitochondria (indicated by the arrow). Bax translocates to the mitochondria and forms foci whereas Cyt $\mathrm{c}$ is released from the mitochondria into the cytosol (indicated by the arrowhead) during apoptosis. (a) Immunofluorescence staining with anti-Bax antibody. (b) Immunofluorescence staining with anti-Cyt c antibody. 
Table 1

Phenotypes of mice or cells deficient in mitochondria proteins other than Bcl-2 family members

\begin{tabular}{|c|c|c|c|c|}
\hline Gene & Knockout detail & KO/KN phenotype & Strain & Reference \\
\hline \multirow[t]{2}{*}{ Cyt c } & Exon 2-3 deleted & $\begin{array}{l}\text { Embryonic lethal (E8.5); resistance to UV, } \\
\text { STS and serum withdrawal; sensitive to } \\
\text { TNFa }\end{array}$ & C57/BLK6/129SVJ & 82 \\
\hline & K72A mutation in exon3 & $\begin{array}{l}\text { Fibroblasts resistant to apoptosis; thymocytes } \\
\text { as sensitive as wild type }\end{array}$ & C57BL/6J & 49 \\
\hline \multirow[t]{2}{*}{ Smac/DIALBO } & Exon 2-4 deleted & Viable; normal apoptosis response & C57BL6/J-129/01a & 100 \\
\hline & Exon 1-2 deleted & $\begin{array}{l}\text { Resistant to certain apoptosis stimuli; Cyt c } \\
\text { release delayed }\end{array}$ & HCT116 & 70 \\
\hline \multirow[t]{2}{*}{$\mathrm{HtrA} 2 / \mathrm{Omi}$} & $83 \%$ coding region deleted & $\begin{array}{l}\text { Death at one month; starting P18 (post birth } \\
\text { day), weight loss, smaller organ size, striatal } \\
\text { neuron loss }\end{array}$ & C57BL/6J & 93 \\
\hline & mnd2 mice:S276C in exon 3 & $\begin{array}{l}\text { Muscle wasting, neurodegeneration, death by } \\
40 \mathrm{~d} \text {; no apoptotic phenotype }\end{array}$ & C57BL/6J & 60 \\
\hline \multirow[t]{3}{*}{ EndoG } & Exon 2 deleted & No apoptotic phenotype & C57BL/6J/129SvJ & 58 \\
\hline & Exon 2, partial exon 3 deleted & No effect on nuclear DNA fragmentation & C57BL/6J/129/SvEvTec & 22 \\
\hline & Exon $1-3$ deleted & $\begin{array}{l}\text { Embryonic lethal; endoG+/-: increased } \\
\text { resistance to apoptosis }\end{array}$ & C57BL/6J/129 & 158 \\
\hline \multirow[t]{6}{*}{ AIF } & Tel.AIF-/-: tissue-specific & $\begin{array}{l}\text { Die by E17, increased cell death of primary } \\
\text { neurons }\end{array}$ & FVB/N and C57/BL6 & 18 \\
\hline & Exon 3 deleted, & $\begin{array}{l}\text { Sensitive to STS, etoposide, UV but resistant } \\
\text { to serum withdrawal }\end{array}$ & E14K male ES cells. & 62 \\
\hline & Hq mice: insertion in intron 1 & $\begin{array}{l}\text { Cerebellar ataxia, optic tract dysfunction, } \\
\text { retinitis pigmentosa }\end{array}$ & & 68 \\
\hline & Exon 7 floxed & $\begin{array}{l}\text { Die by E12.5; muscle-specific: dilated } \\
\text { cardiomyopathy, heart failure, skeletal } \\
\text { muscle atrophy }\end{array}$ & $\mathrm{C} 57 \mathrm{BL} / 7$ & 61 \\
\hline & Exon 7 floxed & Die by E10.5; abnormal cell death & B6CBACa-Aw-1/A & 13 \\
\hline & AIF-/y: exon 1 deleted & $\begin{array}{l}\text { Sensitive to camptothecin, etoposide and } \\
\text { oxidative stress; normal to STS, actinomycin } \\
\text { D, serum starvation, anti-Fas, TRAIL }\end{array}$ & HCT116 and DLD-1 & 128 \\
\hline VDAC1 & Exon $2-5$ deleted & $\begin{array}{l}\text { Viable; deficiency in mito respiration, no } \\
\text { change in PTP }\end{array}$ & C57BL6/129SvEv;CD1 & $2,72,141$ \\
\hline VDAC2 & promoter and exon 1-2 deleted & MEFs more susceptible to apoptosis & C57BL/6/129/SvEv & 17,141 \\
\hline \multirow[t]{3}{*}{ VDAC3 } & Exon 6-9 deleted & Normal PTP and apoptosis & & 141 \\
\hline & VDAC1/VDAC3 & $\begin{array}{l}\text { Normal response to ionomycin-, STS- and } \mathrm{H}_{2} \\
\mathrm{O}_{2} \text {-induced cell death }\end{array}$ & & 8 \\
\hline & VDAC1/VDAC3/VDAC2 RNAi & $\begin{array}{l}\text { Normal response to ionomycin-, STS- and } \mathrm{H}_{2} \\
\mathrm{O}_{2} \text {-induced cell death }\end{array}$ & & 8 \\
\hline ANT1 & Exon 1-3 deleted & $\begin{array}{l}\text { Severe exercise intolerance, reduced } \\
\text { mitochondrial respiration }\end{array}$ & C57BL/6J(B6) & 44 \\
\hline \multirow[t]{2}{*}{ ANT2 } & Exon 3-4 deleted; liver specific & Normal PTP and apoptosis & C57BL/6/129S4 & 71 \\
\hline & ANT1/ANT2 DKO & $\begin{array}{l}\text { Normal response to actinomycin D plus TNF- } \\
\text { a or FasL }\end{array}$ & & 71 \\
\hline CypD & Exon $1-3$ deleted & $\begin{array}{l}\text { Protected from ischaemia/reperfusion-and } \\
\text { oxidative stress-induced not STS or TNF- } \\
\text { alpha-induced cell death }\end{array}$ & Sv129? & 7 \\
\hline
\end{tabular}




\begin{tabular}{l|l|l|l|c}
\hline Gene & Knockout detail & KO/KN phenotype & Strain & Reference \\
\hline & Exon 1-5 deleted & $\begin{array}{l}\text { Normal development; normal response to } \\
\text { apoptosis but resistant to necrotic cell death } \\
\text { induced by ROS and } \mathrm{Ca}^{2+} \text { overload }\end{array}$ & C57BL/6/129/SvEvBrd & 98 \\
\hline
\end{tabular}

